\title{
Functional Reconstitution of the Integral Membrane Enzyme, Isoprenylcysteine Carboxyl Methyltransferase, in Synthetic Bolalipid Membrane Vesicles ${ }^{\dagger}$
}

\author{
Wilma Febo-Ayala, Shakira L. Morera-Félix, Christine A. Hrycyna, and David H. Thompson \\ Department of Chemistry, Purdue University, 560 Oval Drive, West Lafayette, IN 47907-2038, E- \\ mail: davethom@purdue.edu; hrycyna@purdue.edu, FAX: 765-496-2592, Voice: 765-494-0386 \\ (DHT); 765-494-7322 (CAH)
}

\section{Abstract}

Three bipolar archaeal-type diglycerophosphocholine tetraether lipids (a.k.a., bolalipids) have been prepared to determine 1) the influence of molecular structure on the physical properties of bolalipid membranes and 2) their impact on the functional reconstitution of Ste14p, a membrane-associated isoprenylcysteine carboxyl methyltransferase from Saccharomyces cerevisiae. The three bolalipids synthesized were: $\mathrm{C}_{20} \mathrm{BAS}, \mathrm{C}_{32} \mathrm{BAS}$, and $\mathrm{C}_{32}$ phytBAS. These bolalipid structures differ in that the $\mathrm{C}_{20}$ BAS derivative has a short $s n-1$ glyceryl diether $\mathrm{C}_{20} \mathrm{H}_{40}$ transmembrane alkyl chain and two ether-linked $s n$ - $2 n$-decyl chains, whereas the $\mathrm{C}_{32} \mathrm{BAS}$ and $\mathrm{C}_{32}$ phytBAS derivatives have a longer $s n$ - 1 diether $\mathrm{C}_{32} \mathrm{H}_{64}$ membrane-spanning chain and two ether-linked $s n-2 n$-hexadecyl or phytanyl chains, respectively. Differential scanning calorimetry and temperature-dependent ${ }^{31} \mathrm{P}$ NMR was used to determine the gel-to-liquid crystalline phase transition temperatures of the bolalipids $\left(\mathrm{C}_{32} \mathrm{BAS} \mathrm{T} \mathrm{T}_{\mathrm{m}}>85^{\circ} \mathrm{C} ; \mathrm{C}_{32}\right.$ phytBAS $\left.\mathrm{T}_{\mathrm{m}}=14^{\circ} \mathrm{C} ; \mathrm{C}_{20} \mathrm{BAS} \mathrm{T}_{\mathrm{m}}=17^{\circ} \mathrm{C}\right)$. The bolalipid lateral diffusion coefficients, determined by fluorescence recovery after photobleaching at $20^{\circ} \mathrm{C}$, were $1.5 \times 10^{-8}$ and $1.8 \times 10^{-9} \mathrm{~cm}^{2} / \mathrm{s}$ for $\mathrm{C}_{20} \mathrm{BAS}$ and $\mathrm{C}_{32}$ phytBAS, respectively. The mobility of $\mathrm{C}_{32} \mathrm{BAS}$ could not be measured at this temperature. Ste14p activity was monitored by an in vitro methyltransferase assay in reconstituted vesicle dispersions composed of DMPC, $\mathrm{C}_{20} \mathrm{BAS}$ :E. coli polar lipid, $\mathrm{C}_{20} \mathrm{BAS}$ :POPC, $\mathrm{C}_{32}$ phytBAS:E. coli polar lipid, and $\mathrm{C}_{32}$ phytBAS:POPC. Ste $14 \mathrm{p}$ activity was lost in vesicles composed of 75-100 mol $\% \mathrm{C}_{20} \mathrm{BAS}$ and 0-100 mol $\% \mathrm{C}_{32} \mathrm{BAS}$, but retained in vesicles with 0-50 mol $\% \mathrm{C}_{20} \mathrm{BAS}$ and 0-100 mol\% $\mathrm{C}_{32}$ phytBAS. Confocal immunofluorescence microscopy confirmed the presence of Ste $14 \mathrm{p}$ in $100 \mathrm{~mol} \% \mathrm{C}_{20} \mathrm{BAS}$ and $100 \mathrm{~mol} \% \mathrm{C}_{32}$ phytBAS vesicle dispersions, even though the lamellar liquid crystalline phase thickness of $\mathrm{C}_{20} \mathrm{BAS}$ is only $32 \AA$. Since Ste14p activity was not affected by either the gel to liquid-crystal phase transition temperature of the lipid or the temperature of the assay, the low activity observed in $75-100 \mathrm{~mol} \% \mathrm{C}_{20} \mathrm{BAS}$ membranes can be attributed to hydrophobic mismatch between this bolalipid and the hydrophobic surface of Ste14p.

\begin{abstract}
Bolalipids, also called bolaamphiphiles, are a class of bipolar lipids found in the cell membranes of some Archaea. In many cases, these organisms can survive in extreme environments due to the presence of isoprenoid-based tetraether bolalipids in their membranes (1-5). The membrane-spanning bipolar structural motif confers increased stability to these membranes by effectively cross-linking the apposed leaflets of a bilayer membrane, thereby producing a monolayer membrane that functionally mimics a conventional membrane bilayer.
\end{abstract}

\footnotetext{
${ }^{\dagger}$ This work was supported by NIH CA112427, the NIH "Diversity in Biomedical Science Program" at Purdue University, and the Indiana $21^{\text {st }}$ Century Fund.

Correspondence to: Christine A. Hrycyna; David H. Thompson.
} 
This membrane stabilization strategy blocks membrane failure via delamination in the physically and chemically challenging environments that are often preferred by this class of organism. Archaeal bolalipid structures are characterized by ether linkages to each glycerol backbone, nonitol or phosphate polar headgroups, and transmembrane chains that contain combinations of methyl branching and cyclopentane rings to help maintain membrane fluidity across a wide range of environmental temperatures (6-7). Studies of biogenic and synthetic variants of these unusual membrane materials demonstrate that bolalipid membranes are less permeable and more durable than membranes composed of monopolar lipids (8-13). This unique combination of properties has ignited interest in their use as non-polymeric membrane stabilizing agents in applications such as drug delivery and membrane protein-based biosensors $(5,12,14,15)$.

Biosensor and drug delivery applications of bolalipids will require large quantities of material. Unfortunately, bolalipids derived from Archaea are difficult to obtain in pure form on even the $1 \mathrm{mg}$ scale. We report three synthetic archaeal bolalipid mimics that retain key structural motifs of naturally occurring bolalipids, yet are easier to produce in >100 mg quantities: 2,2'di-O-decyl-3,3'-di-O-(1',20"'-eicosanyl)-bis-(rac-glycero)-1,1'-diphosphocholine (C 20 BAS), 2,2'-di-O-hexadecyl-3,3'-di-O-(1',32'-dotriacontanyl)-bis-(rac-glycero)-1,1'diphosphocholine $\left(\mathrm{C}_{32} \mathrm{BAS}\right)$ and 2,2'-di-O-(3,7,11,15-tetramethylhexadecyl)-3,3'-di-O-(1', 32"-dotriacontanyl)-bis-(rac-glycero)-1,1'-diphosphocholine $\left(\mathrm{C}_{32}\right.$ phytBAS) (Figure 1). Each of these bolalipid structures is acyclic, symmetric, contains glycerophosphocholine headgroups, and possesses either 20 or 32 carbon transmembrane chains to stabilize the hydrophobic domains of integral membrane proteins. The hydrophobic chains at each $s n-2$ position of the bolalipid glycerol backbones are both $n$-alkyl or phytanyl, with lengths that are half that of the transmembrane chain. Methyl branching was designed into the $\mathrm{C}_{32}$ phytBAS structure, since is was expected that the phytanyl chains would lower the bolalipid gel to liquidcrystalline phase transition temperature relative to $\mathrm{C}_{32} \mathrm{BAS}$ by disrupting the alkyl chain packing within the membrane.

In this report, the first successful reconstitution of an integral membrane protein in synthetic bolalipid vesicles and the correlation of its activity with the physical properties of the membrane is demonstrated. The only prior reports of integral membrane protein enzymes in bolalipid vesicles described the use of the polar lipid extract from the thermophile $S$. acidocaldarius to functionally reconstitute beef heart cytochrome c-oxidase (16) and the leucine transporter of Lactococcus lactis (17). These studies, however, did not provide insight into the role of bolalipid structure and physical properties on the function of these membrane proteins.

The isoprenylcysteine carboxyl methyltransferase (Icmt) from Saccharomyces cerevisiae, Ste 14p, was chosen for functional reconstitution into bolalipid membranes. Ste $14 \mathrm{p}$ is a $26 \mathrm{kDa}$ integral membrane protein with six transmembrane domains and a predicted topology as shown in Scheme 1 (18). It is a polytopic endoplasmic reticulum membrane-localized Icmt enzyme that is responsible for carboxyl methylation of C-terminal CaaX sequences (C is cysteine, "a" is generally an aliphatic residue, $\mathrm{X}$ can be one of many amino acids). Carboxyl methylation of CaaX sequences is essential for the proper localization and transformation ability of oncogenic Ras proteins, thus making it an important target for chemotherapeutic agent discovery. We used the $37 \mathrm{kD}$ His $10 m y c_{3}$-tagged variant of Ste14p as a model enzyme for human Icmt in this study because 1) they are functional homologs (19) and 2) it has previously been successfully purified and functionally reconstituted in conventional lipids (20). A supported membrane sensor constructed from human Icmt-containing bolalipids may be useful for screening Icmt inhibitor candidates, therefore, reconstitution of functional Ste14p in bolalipid vesicles is an essential first step toward the development of a sensor based on this enzyme. Unfortunately, to date, attempts at purifying and functionally reconstituting human and other mammalian Icmts have met with limited to no success (21-24). 
This contribution describes the characterization of $\mathrm{C}_{20} \mathrm{BAS}, \mathrm{C}_{32} \mathrm{BAS}$ and $\mathrm{C}_{32}$ phytBAS by differential scanning calorimetry (DSC), temperature-dependent ${ }^{31} \mathrm{P}$ NMR, and fluorescence recovery after photobleaching (FRAP). The impact of bolalipid structure and membrane composition on Ste14p activity, monitored by an in vitro vapor diffusion methyltransferase assay (20), was then determined using vesicles of differing lipid composition, gel to liquid crystalline phase transition temperatures, and lipid mobility. Confocal immunofluorescence microscopy and protein assays were used to determine the extent and distribution of Ste14p in reconstituted vesicle membranes. Our results show that Ste $14 \mathrm{p}$ activity is sensitive to hydrophobic mismatch between the bolalipid membrane and the hydrophobic surface of Ste14p, however, it is not sensitive to the phase state of the host membrane. These findings suggest that $\mathrm{C}_{32}$ phytBAS is an excellent candidate for a rugged host membrane material for Ste14p sensor production.

\section{MATERIALS AND METHODS}

\section{Materials}

The synthesis of $\mathrm{C}_{20} \mathrm{BAS}$ has been previously described (25,26). $\mathrm{C}_{32}$ phytBAS and $\mathrm{C}_{32} \mathrm{BAS}$ were synthesized as described below. POPC (1-palmitoyl-2-oleoyl-sn-glycero-3phosphocholine), DMPC (1,2-dimyristoyl-sn-glycero-3-phosphocholine), cholesterol (Chol), E. coli polar lipid extract and 1-oleoyl-2-[6-[(7-nitro-2-1,3-benzoxadiazol-4-yl)amino] hexanoyl]-sn-glycero-3-phosphocholine (NBD-OPPC) were purchased from Avanti Polar Lipids (Alabaster, AL). Fluorescein-labeled anti-myc-FITC mouse antibodies were obtained from Invitrogen (Carlsbad, CA). $N$-Acetyl-S-farnesyl-L-cysteine (AFC) was provided by Dr. Richard Gibbs (Purdue University). $S$-Adenosyl-L- $\left[{ }^{14} \mathrm{C}\right.$-methyl $]$ methionine $\left({ }^{14} \mathrm{C}\right.$-SAM) was purchased from Amersham Biosciences (Uppsala, Sweden). 1-Dodecyl- $\beta$-D-maltopyranoside $(\mathrm{DDM})$ was obtained from Anatrace, Inc. (Maumee, $\mathrm{OH}$ ). Triton ${ }^{\circledR} \mathrm{X}$ was obtained from Sigma (St. Louis, MO). HPLC grade chloroform $\left(\mathrm{CHCl}_{3}\right)$, diethyl ether $\left(\mathrm{Et}_{2} \mathrm{O}\right)$, and methanol $(\mathrm{MeOH})$ were supplied by Mallinckrodt-Baker (Paris, KY). All chemicals for the synthesis of $\mathrm{C}_{32}$ phytBAS and $\mathrm{C}_{32} \mathrm{BAS}$ were purchased from Aldrich except for 2-chloro-2-oxo-1,3,2dioxaphospholane (Fluka, Milwaukee, WI). Reaction solvents were reagent grade and were dried by distillation from an appropriate dessicant under $\mathrm{N}_{2}$ before use: tetrahydrofuran (THF) from sodium benzophenone ketyl; dichloromethane $\left(\mathrm{CH}_{2} \mathrm{Cl}_{2}\right)$, toluene $\left(\mathrm{PhCH}_{3}\right)$, acetonitrile $\left(\mathrm{CH}_{3} \mathrm{CN}\right)$, and triethylamine $\left(\mathrm{Et}_{3} \mathrm{~N}\right)$ from $\mathrm{CaH}_{2}$. All reactions were performed under dry Ar or $\mathrm{N}_{2}$ gas. NMR spectra were recorded on a Varian $300 \mathrm{MHz}$ spectrometer using ${ }^{1} \mathrm{H}$ and ${ }^{13} \mathrm{C}$ solvent peaks as the internal reference. Column chromatography was performed with 230-400 mesh silica gel using HPLC grade eluents. Electrospray mass spectrometry (ESI MS) was performed using a Waters ZQ spectrometer. Thin layer chromatography was performed using Baker-flex IB-F plates (J.T. Baker) and visualized using UV, $\mathrm{I}_{2}$ adsorption, $\mathrm{KMnO}_{4} /$ heat, and/ or $\mathrm{H}_{2} \mathrm{SO}_{4} /$ heat.

\section{Synthesis of $\mathrm{C}_{32}$ phytBAS}

The synthesis route for $\mathrm{C}_{32}$ phytBAS (Scheme 2) was adapted from a method described for the preparation of $\mathrm{C}_{20} \mathrm{BAS}(25,26)$.

(E)-1-lodo-3,7,11,15-tetramethylhexadec-2-ene (1)—A flame dried flask was charged with $\mathrm{PPh}_{3}(1.0557 \mathrm{~g}, 4.04 \mathrm{mmol})$ followed by $11 \mathrm{~mL}$ of $\mathrm{CH}_{2} \mathrm{Cl}_{2}$ and imidazole $(0.2776 \mathrm{~g}, 4.04$ $\mathrm{mmol})$. The solution was cooled to $0{ }^{\circ} \mathrm{C}, \mathrm{I}_{2}$ crystals $(1.0273 \mathrm{~g}, 4.04 \mathrm{mmol})$ added slowly, and the mixture stirred at $25^{\circ} \mathrm{C}$ for $15 \mathrm{~min}$ under Ar. Phytol $(1.0 \mathrm{~g}, 3.37 \mathrm{mmol})$ in $3 \mathrm{~mL} \mathrm{CH} \mathrm{Cl}_{2}$ was then added and the mixture stirred at $25^{\circ} \mathrm{C}$ under Ar for an additional $2 \mathrm{~h}$. Petroleum ether $(200 \mathrm{~mL})$ was then added and the mixture filtered twice through a 1" pad of silica gel. After solvent removal, $0.874 \mathrm{~g}$ of $\mathbf{1}$ (63\% yield) was obtained as a light yellow oil. ${ }^{1} \mathrm{H}$ NMR (300 $\left.\mathrm{MHz}, \mathrm{CDCl}_{3}\right): 0.88$ (t, $\left.12 \mathrm{H}, \mathrm{CH}_{3}\right) ; 0.99-1.41\left(\mathrm{~m}, 19 \mathrm{H}, \mathrm{CH}+\mathrm{CH}_{2}\right.$ aliphatic); 1.63 (s, $3 \mathrm{H}$, 
$\mathrm{CH}_{3}$ vinylic); 1.98 (t, $2 \mathrm{H}, \mathrm{CH}_{2}$ allylic); 3.94 (d, $\left.2 \mathrm{H}, \mathrm{CH}_{2} \mathrm{I}\right) ; 5.532$ (t, $1 \mathrm{H}, \mathrm{CH}$ vinylic). ${ }^{13} \mathrm{C}$ NMR (75 MHz, $\left.\mathrm{CDCl}_{3}\right): 4.10,15.71,19.71,19.77,22.63,22.73,24.47,24.80,24.91,27.98$, 32.66, 32.80, 36.43, 37.29, 37.36, 37.44, 39.38, 39.88, 121.67, 142.88. ESI ${ }^{+} \mathrm{MS}: \mathrm{m} / \mathrm{z}(\mathrm{M}+\mathrm{H})$ 461.

(E)-2-Phenyl-5-O-(3,7,11,15-tetramethylhexadec-2-enyl)-1,3-dioxane (2)—A flame-dried flask was charged with 2-phenyl-5-hydroxy-1,3-dioxane $(0.322 \mathrm{~g}, 1.79 \mathrm{mmol})$ followed by $4 \mathrm{~mL}$ THF before cooling to $0{ }^{\circ} \mathrm{C}$. NaH dispersion ( $80 \%$ in oil, $0.1485 \mathrm{~g}, 4.95$ mmol) was slowly added and the mixture stirred at $25^{\circ} \mathrm{C}$ for $1 \mathrm{~h}$. Compound $\mathbf{1}(0.874 \mathrm{~g}, 2.15$ mmol) was dissolved in $3 \mathrm{~mL}$ THF and slowly added to the alkoxide solution at $0{ }^{\circ} \mathrm{C}$ prior to heating at reflux overnight under Ar. The unreacted $\mathrm{NaH}$ was quenched at $0{ }^{\circ} \mathrm{C}$ with deionized $\mathrm{H}_{2} \mathrm{O}$. The aqueous phase was extracted with $\mathrm{Et}_{2} \mathrm{O}(3 \times 25 \mathrm{~mL})$, the organic phases combined, dried over $\mathrm{MgSO}_{4}$, filtered, and the solvent removed by rotary evaporation. The crude mixture was separated via column chromatography using gradient elution: $100 \%$ hexane to $1: 1$ hexane: $\mathrm{CH}_{2} \mathrm{Cl}_{2}$. Fractions containing the desired product were pooled, the solvent removed by rotary evaporation, and the residue dried under vacuum to give $0.879 \mathrm{~g}$ (100\% yield) of 2 as a clear oil. ${ }^{1} \mathrm{H}$ NMR $\left(300 \mathrm{MHz}, \mathrm{CDCl}_{3}\right): 0.86\left(\mathrm{t}, 12 \mathrm{H}, \mathrm{CH}_{3}\right) ; 1.05-1.57(\mathrm{~m}, 19 \mathrm{H}, \mathrm{CH}$ $+\mathrm{CH}_{2}$ aliphatic); 1.65 (s, $3 \mathrm{H}, \mathrm{CH}_{3}$ vinylic); $1.99\left(\mathrm{~m}, 2 \mathrm{H}, \mathrm{CH}_{2}\right.$ allylic), 3.29 (s, $\left.1 \mathrm{H}, \mathrm{CH}-\mathrm{O}\right)$; $4.01\left(\mathrm{dd}, 2 \mathrm{H}, \mathrm{OCH}_{2}\right) ; 4.15\left(\mathrm{dd}, 2 \mathrm{H}, \mathrm{OCH}_{2}\right.$ allylic), $4.31\left(\mathrm{dd}, 2 \mathrm{H}, \mathrm{OCH}_{2}\right), 5.39$ (t, $1 \mathrm{H}, \mathrm{CH}$ vinylic), 5.53 (s, $1 \mathrm{H}$, OCHO acetal), 7.32 (dd, $3 \mathrm{H}$, phenyl), 7.51 (dd, $2 \mathrm{H}$, phenyl). ${ }^{13} \mathrm{C}$ NMR (75 MHz, $\mathrm{CDCl}_{3}$ ): 16.33, 19.62, 22.53, 22.62, 24.35, 24.69, 24.97, 27.85, 32.57, 32.67, 36.58, $37.18,37.26,37.32,39.26,39.80,64.92,68.97,69.16,101.14,120.66,126.10,127.97,128.64$, 138.04, 140.29. $\mathrm{ESI}^{+} \mathrm{MS}: \mathrm{m} / \mathrm{z}\left(\mathrm{M}^{+}\right) 458$.

2-Phenyl-5-0-(3,7,11,15-tetramethylhexadecyloxy)-1,3-dioxane (3)—A flask was charged with $2(0.12 \mathrm{~g}, 0.262 \mathrm{mmol})$ followed by $27 \mathrm{~mL}$ of a 9:1 EtOH:THF solution and Wilkinson's catalyst $\left(\mathrm{Rh}\left(\mathrm{PPh}_{3}\right)_{3} \mathrm{Cl}, 10 \mathrm{mg}, 0.01 \mathrm{mmol}\right)$. The mixture was stirred under $1 \mathrm{~atm}$ of $\mathrm{H}_{2}$ at $25{ }^{\circ} \mathrm{C}$ overnight and filtered through a 0.5 " pad of alumina, followed by a $\sim 100 \mathrm{~mL}$ $\mathrm{Et}_{2} \mathrm{O}$ rinse. The solvent was removed on a rotary evaporator and the crude product purified via column chromatography using hexane: $\mathrm{CH}_{2} \mathrm{Cl}_{2}$ as eluent. Fractions containing the product were pooled and the solvent removed on a rotary evaporator to give $0.103 \mathrm{~g}$ of $\mathbf{3}$ (85\% yield) as a clear oil. ${ }^{1} \mathrm{H}$ NMR $\left(300 \mathrm{MHz}, \mathrm{CDCl}_{3}\right): 0.854\left(\mathrm{q}, 15 \mathrm{H}, \mathrm{CH}_{3}\right) ; 1.04-1.59\left(\mathrm{~m}, 22 \mathrm{H}, \mathrm{CH}+\mathrm{CH}_{2}\right.$ aliphatic); $1.68-1.72\left(\mathrm{~m}, 2 \mathrm{H}, \mathrm{CH}_{2} \beta\right.$ to $\mathrm{O}$ ); 3.25 (s, $\left.1 \mathrm{H}, \mathrm{CH}-\mathrm{O}\right) ; 3.58\left(\mathrm{~m}, 2 \mathrm{H}, \mathrm{OCH}_{2}\right) ; 4.03+$ 4.33 (dd, $\left.4 \mathrm{H}, \mathrm{OCH}_{2}\right) ; 5.54$ (s, $1 \mathrm{H}, \mathrm{CH}$ acetal); $7.34+7.51$ (dd, $5 \mathrm{H}$, phenyl). ${ }^{13} \mathrm{C}$ NMR $(75$ $\left.\mathrm{MHz}, \mathrm{CDCl}_{3}\right): 19.73,22.60,22.70,24.33,24.46,24.77,27.94,29.89,32.77,36.70,36.78$, 37.26, 37.29, 37.42, 37.47, 39.33, 67.23, 68.97, 69.05, 70.57, 101.29, 126.16, 128.11, 128.78, 138.14. $\mathrm{ESI}^{+} \mathrm{MS}: \mathrm{m} / z(\mathrm{M}+\mathrm{H}) 461$.

1-O-Benzyl-2-0-(3,7,11,15-tetramethylhexadecyl)-rac-glycerol (4)-A flame-dried flask was charged with $3(2.98 \mathrm{~g}, 6.47 \mathrm{mmol})$ followed by $14 \mathrm{~mL} \mathrm{CH}_{2} \mathrm{Cl}_{2}$, and then cooled to $-78^{\circ} \mathrm{C}$. Diisobutylaluminum hydride (DIBAL-H, $7.12 \mathrm{~mL}$ of a $1 \mathrm{M}$ solution in $\mathrm{CH}_{2} \mathrm{Cl}_{2}, 7.12$ mmol) was added dropwise via syringe and the reaction stirred at $-78{ }^{\circ} \mathrm{C}$ for $1 \mathrm{~h}$ under $\mathrm{Ar}$ before slowly warming to $25^{\circ} \mathrm{C}$ and stirring overnight. The reaction was then cooled to $0{ }^{\circ} \mathrm{C}$, quenched with $600 \mu \mathrm{L}$ of $\mathrm{MeOH}$, and $\mathrm{NaOH}$ solution added to disperse the gel $(10 \mathrm{~mL}$ of a 5 $\mathrm{N} \mathrm{NaOH}$ solution). The aqueous phase was extracted with $\mathrm{Et}_{2} \mathrm{O}(3 \times 50 \mathrm{~mL})$, the organic phases combined, dried over $\mathrm{MgSO}_{4}$, filtered, evaporated, and the residue dried under vacuum to give $2.676 \mathrm{~g}$ of 4 (89\% yield) as a colorless oil. ${ }^{1} \mathrm{H} \mathrm{NMR}\left(300 \mathrm{MHz}, \mathrm{CDCl}_{3}\right): 0.86\left(\mathrm{t}, 15 \mathrm{H}, \mathrm{CH}_{3}\right)$; $1.23\left(\mathrm{~m}, 22 \mathrm{H}, \mathrm{CH}+\mathrm{CH}_{2}\right.$ aliphatic); $1.56\left(\mathrm{~m}, 2 \mathrm{H}, \mathrm{CH}_{2} \beta\right.$ to O); 2.34 (t, $\left.1 \mathrm{H}, \mathrm{OH}\right), 3.63(\mathrm{~m}, 7$ $\left.\mathrm{H}, \mathrm{CH}-\mathrm{O}+\mathrm{OCH}_{2}\right), 4.53$ (s, $2 \mathrm{H}, \mathrm{OCH}_{2} \mathrm{Ph}$ ), 7.29 (bs, $5 \mathrm{H}$, phenyl). ${ }^{13} \mathrm{C} \mathrm{NMR}(75 \mathrm{MHz}$, $\left.\mathrm{CDCl}_{3}\right): 19.53,19.62,19.68,22.55,22.64,24.27,24.40,24.71,27.87,29.74,32.70,37.00$, $37.08,37.21,37.24,37.27,37.31,37.37,37.42,39.29,62.67,68.58,69.92,73.40,78.54$, 127.51, 127.56, 128.28, 137.96. ESI ${ }^{+} \mathrm{MS}: \mathrm{m} / z(\mathrm{M}+\mathrm{H}) 463$. 
17-Bromo-1-heptadecene (5)-This precursor was prepared as described by Peanasky et al. (27). ${ }^{1} \mathrm{H} \mathrm{NMR}\left(300 \mathrm{MHz}, \mathrm{CDCl}_{3}\right): 1.25\left(\mathrm{~s}, 24 \mathrm{H},-\mathrm{CH}_{2}\right), 1.85\left(\mathrm{q}, 2 \mathrm{H},-\mathrm{CH}_{2}\right), 2.25$ (q, $2 \mathrm{H}$, allylic $\left.-\mathrm{CH}_{2}\right), 3.40\left(\mathrm{t}, 2 \mathrm{H},-\mathrm{CH}_{2} \mathrm{Br}\right), 4.95\left(\mathrm{dd}, 2 \mathrm{H}\right.$, vinyl $\left.\mathrm{CH}_{2}\right), 5.8(\mathrm{~m}, 1 \mathrm{H}$, vinyl $\mathrm{CH}) .{ }^{13} \mathrm{C}$ NMR $\left(75 \mathrm{MHz}, \mathrm{CDCl}_{3}\right)$ : 28.4, 29.0, 29.2, 29.4, 29.7, 29.7, 29.8, 29.8, 29.9, 29.9, 33.1, 34.0, $34.2,76.8,77.2,77.7,114.3,139.5$. $\mathrm{ESI}^{+} \mathrm{MS}: \mathrm{m} / z(\mathrm{M}+\mathrm{H}) 317 / 319$.

\section{1-Benzyl-2-0-(3,7,11,15-tetramethylhexadecyl)-3-0-(16'-heptadecenyl)-rac-}

glycerol (6)-A flame-dried flask was charged with $4(2.676 \mathrm{~g}, 5.78 \mathrm{mmol})$ in $10 \mathrm{~mL}$ THF and cooled to $0{ }^{\circ} \mathrm{C}$. $\mathrm{NaH}(0.1457 \mathrm{~g}, 6.07 \mathrm{mmol})$ was added slowly and stirred at $25^{\circ} \mathrm{C}$ for $1 \mathrm{~h}$ under Ar. A solution of $5(5.68 \mathrm{~g}, 0.0179 \mathrm{~mol})$ in $10 \mathrm{~mL}$ THF was slowly added at $0{ }^{\circ} \mathrm{C}$ and stirred at $25^{\circ} \mathrm{C}$ for $2 \mathrm{~d}$ under Ar. Water $(25 \mathrm{~mL})$ was added and the aqueous phase extracted with $\mathrm{Et}_{2} \mathrm{O}(3 \times 50 \mathrm{~mL})$. The organic phase was separated, dried over $\mathrm{MgSO}_{4}$, filtered and evaporated on a rotary evaporator. The crude product was purified by column chromatography using gradient elution: 1:1 hexane: $\mathrm{CH}_{2} \mathrm{Cl}_{2}$ to $100 \% \mathrm{CH}_{2} \mathrm{Cl}_{2}$. The fractions containing the desired product were pooled, evaporated and the residue dried under vacuum to give $1.187 \mathrm{~g}$ of 6 (29\% yield). ${ }^{1} \mathrm{H}$ NMR ( $\left.300 \mathrm{MHz}, \mathrm{CDCl}_{3}\right): 0.86\left(\mathrm{t}, 15 \mathrm{H}, \mathrm{CH}_{3}\right) ; 1.21(\mathrm{~m}, 46 \mathrm{H}, \mathrm{CH}$ $+\mathrm{CH}_{2}$ aliphatic); 1.57 ( $\mathrm{m}, 4 \mathrm{H}, \mathrm{CH}_{2} \beta$ to O); 2.03 (q, $2 \mathrm{H}, \mathrm{CH}_{2}$ allylic), $3.54(\mathrm{~m}, 9 \mathrm{H}, \mathrm{CH}-\mathrm{O}+$ $\mathrm{OCH}_{2}$ ), 4.55 (s, $2 \mathrm{H}, \mathrm{OCH}_{2} \mathrm{Ph}$ ), 4.95 (dd, $2 \mathrm{H}, \mathrm{CH}_{2}$ vinyl), 5.81 (m, $1 \mathrm{H}, \mathrm{CH}$ vinyl), 7.29 (bs, $5 \mathrm{H}$, phenyl). ${ }^{13} \mathrm{C}$ NMR $\left(75 \mathrm{MHz}, \mathrm{CDCl}_{3}\right): 19.74,22.61,22.71,24.35,24.47,24.79,26.12$, $27.95,28.94,29.15,29.50,29.68,29.78,32.78,33.81,37.38,37.45,39.35,68.85,70.26,70.72$, 71.64, 73.33, 77.92, 114.06, 126.04, 127.47, 127.56, 127.67, 128.28, 139.20. ESI ${ }^{+} \mathrm{MS}: \mathrm{m} / \mathrm{z}$ $(\mathrm{M}+\mathrm{H}) 699$.

1,1'-Di-O-benzyl-2,2'-di-O-(3,7,11,15-tetramethylhexadecyl)-3,3'-di-O-(1",32'dotriacont-16"-enyl)-bis-(rac-glycerol) (7)—A flame dried flask was charged with 6 $(1.927 \mathrm{~g}, 2.76 \mathrm{mmol})$ and $6 \mathrm{~mL} \mathrm{CH} \mathrm{Cl}_{2}$. Grubbs catalyst $\left(\mathrm{Ru}(\mathrm{CHPh})\left(\mathrm{PCy}_{3}\right)_{3} \mathrm{Cl}_{2}, 0.2268 \mathrm{~g}\right.$, $0.276 \mathrm{mmol}$ ) in $5 \mathrm{~mL} \mathrm{CH}_{2} \mathrm{Cl}_{2}$ was slowly added before heating the mixture at reflux overnight. After cooling the reaction mixture, the catalyst was quenched with $10 \mathrm{~mL} \mathrm{H}_{2} \mathrm{O}$ and the aqueous phase extracted with $\mathrm{CH}_{2} \mathrm{Cl}_{2}(3 \times 10 \mathrm{~mL})$. The organic phase was then dried over $\mathrm{MgSO}_{4}$, filtered and the solvent evaporated on a rotary evaporator. The crude product was purified via column chromatography using gradient elution: 9:1 to 6:4 hexane:Et ${ }_{2} \mathrm{O}$. Fractions containing the desired product were pooled, evaporated and the residue dried under vacuum to give 1.177 g of 7 (62\% yield) as a light brown oil. ${ }^{1} \mathrm{H}$ NMR $\left(300 \mathrm{MHz}, \mathrm{CDCl}_{3}\right): 0.86\left(\mathrm{t}, 30 \mathrm{H}, \mathrm{CH}_{3}\right) ; 1.25$ (m, $92 \mathrm{H}, \mathrm{CH}+\mathrm{CH}_{2}$ aliphatic); 1.57 (m, $8 \mathrm{H}, \mathrm{CH}_{2} \beta$ to O); 1.96 (c, $4 \mathrm{H}, \mathrm{CH}_{2}$ allylic), 3.52 (m, $\left.18 \mathrm{H}, \mathrm{CH}-\mathrm{O}+\mathrm{OCH}_{2}\right), 4.55$ (s, $\left.4 \mathrm{H}, \mathrm{OCH}_{2} \mathrm{Ph}\right), 5.37$ (m, $2 \mathrm{H}, \mathrm{CH}_{2}$ vinyl), 7.29 (bs, $10 \mathrm{H}$, phenyl). ${ }^{13} \mathrm{C}$ NMR $\left(75 \mathrm{MHz}, \mathrm{CDCl}_{3}\right)$ : 19.83, 19.91, 19.96, 22.84, 22.93, 24.57, 24.70, 25.01, $26.35,28.17,29.40,29.72,29.76,29.89,29.92,30.00,32.82,33.00,33.31,37.39,37.50,37.62$, $37.67,37.72,39.58,69.05,70.52,70.97,71.85,73.55,78.17,127.66,127.75,128.47,130.06$, 130.53, 138.64. $\mathrm{ESI}^{+} \mathrm{MS}: \mathrm{m} / z\left(\mathrm{M}+\mathrm{Na}^{+}\right) 1393$.

2,2'-Di-O-(3,7,11,15-tetramethylhexadecyl)-3,3'-di-O-(1",32"-dotriacontanyl)bis-(rac-glycerol) (8)—A flask was charged with 7 (1.094 g, $0.798 \mathrm{mmol})$ followed by 25 $\mathrm{mL}$ of a 4:1 THF:EtOH solvent mixture, $20 \% \mathrm{Pd}(\mathrm{OH})_{2}$ on carbon catalyst $(0.168 \mathrm{~g}, 0.234$ mmol) and the mixture stirred under $1 \mathrm{~atm} \mathrm{H}_{2}$ at $25^{\circ} \mathrm{C}$ overnight. The catalyst was removed by filtration through a 0.5 " pad of Celite, followed by a $\sim 100 \mathrm{~mL} \mathrm{CHCl}_{3}$ rinse. The solvent was removed by rotary evaporation and the crude product purified by column chromatography using 3:1 hexane: $\mathrm{Et}_{2} \mathrm{O}$ as eluent. Fractions containing the desired product were pooled, evaporated, and the residue dried under vacuum to give $0.738 \mathrm{~g}$ (78\% yield) of $\mathbf{8}$ as an ivory wax. ${ }^{1} \mathrm{H}$ NMR (300 MHz, $\left.\mathrm{CDCl}_{3}\right): 0.87$ (t, $\left.30 \mathrm{H}, \mathrm{CH}_{3}\right) ; 1.25$ (m, $100 \mathrm{H}, \mathrm{CH}+\mathrm{CH}_{2}$ aliphatic); $1.57\left(\mathrm{~m}, 8 \mathrm{H}, \mathrm{CH}_{2} \beta\right.$ to O); 2.22 (t, $\left.2 \mathrm{H}, \mathrm{OH}\right), 3.57\left(\mathrm{~m}, 18 \mathrm{H}, \mathrm{CH}-\mathrm{O}+\mathrm{OCH}_{2}\right) .{ }^{13} \mathrm{C} \mathrm{NMR}(75$ $\left.\mathrm{MHz}, \mathrm{CDCl}_{3}\right): 19.97,22.85,22.95,24.58,24.71,25.03,26.33,28.20,29.72,29.86,29.94$, 
33.03, 37.37, 37.52, 37.69, 39.60, 63.32, 68.86, 71.15, 72.08, 78.51. ESI ${ }^{+} \mathrm{MS}: \mathrm{m} / z(\mathrm{M}+\mathrm{H})$ 1192.

2,2'-Di-O-(3,7,11,15-tetramethylhexadecyl)-3,3'-di-O-(1",32'-dotriacontanyl)bis-(rac-glycero)-1,1'-diphosphocholine $\left(\mathrm{C}_{32}\right.$ phytBAS, 9 ) -A flame dried flask was charged with $8(0.150 \mathrm{~g}, 0.125 \mathrm{mmol})$, followed by the addition of $0.25 \mathrm{~mL}$ THF, 2-oxo-2chloro-1,3,2-dioxaphospholane $(0.15 \mathrm{~mL}, 1.13 \mathrm{mmol})$, and $\mathrm{Et}_{3} \mathrm{~N}(0.12 \mathrm{~mL}, 0.565 \mathrm{mmol})$. The turbid mixture was diluted with $2 \mathrm{~mL}$ THF and $1 \mathrm{~mL}$ DMF. The reaction mixture was then transferred to a flame-dried pressure tube and $1 \mathrm{~mL} \mathrm{Me} 3 \mathrm{~N}$ condensed into the tube. The tube was then sealed and heated to $70{ }^{\circ} \mathrm{C}$ with stirring for $2 \mathrm{~d}$. The reaction vessel was then slowly cooled to $0{ }^{\circ} \mathrm{C}$, the pressure carefully released, and the product mixture concentrated on a rotary evaporator. The product was isolated by silica gel column chromatography using step gradient elution: 80:20:0, 0:100:0, 65:35:5, 60:40:10 $\mathrm{CHCl}_{3}: \mathrm{MeOH}: \mathrm{H}_{2} \mathrm{O}$. Suspended silica particles were removed from the fractions using a $0.22 \mu \mathrm{m}$ PTFE filter, the solvent evaporated, and the residue dried under vacuum to give $0.1903 \mathrm{~g}$ of $\mathbf{9}\left(81 \%\right.$ yield) as a wax. ${ }^{1} \mathrm{H}$ NMR $(300 \mathrm{MHz}$, $\left.\mathrm{CDCl}_{3}: \mathrm{CD}_{3} \mathrm{OD}\right): 0.86\left(\mathrm{t}, 30 \mathrm{H}, \mathrm{CH}_{3}\right) ; 1.19\left(\mathrm{~m}, 100 \mathrm{H}, \mathrm{CH}+\mathrm{CH}_{2}\right.$ aliphatic); $1.53(\mathrm{~m}, 8 \mathrm{H}$, $\mathrm{CH}_{2} \beta$ to O); 3.23 (s, $\left.18 \mathrm{H}, \mathrm{NMe}_{3}\right), 3.49\left(\mathrm{~m}, 18 \mathrm{H}, \mathrm{CH}-\mathrm{O}+\mathrm{OCH}_{2}\right), 3.90\left(\mathrm{t}, 4 \mathrm{H}, \mathrm{CH}_{2} \mathrm{~N}\right), 4.25$ (bs, $4 \mathrm{H}, \mathrm{CH}_{2} \mathrm{OP}$ ). ${ }^{13} \mathrm{C}$ NMR (75 MHz, $\mathrm{CDCl}_{3}: \mathrm{CD}_{3} \mathrm{OD}$ ): 21.16, 21.24, 24.12, 24.20, 26.04, 26.37, 27.67, 29.52, 31.28, 34.37, 38.84, 39.01, 40.94, 55.76, 60.52, 66.69, 68.08, 70.43, 70.62, 72.17, 73.33. ${ }^{31} \mathrm{P} \mathrm{NMR}\left(124 \mathrm{MHz}, \mathrm{CDCl}_{3}: \mathrm{CD}_{3} \mathrm{OD}\right.$ ): single peak (unreferenced) confirms the presence of a single phosphorus bonding motif. $\mathrm{ESI}^{+} \mathrm{MS}: \mathrm{m} / \mathrm{z}(\mathrm{M}+\mathrm{H}) 1522$.

\section{Synthesis of $\mathrm{C}_{32} \mathrm{BAS}$}

The synthesis route for $\mathrm{C}_{32} \mathrm{BAS}$ is shown in Scheme 3 .

1-O-Benzyl-2-hexadecyloxy-3-0-(16'-heptadecenoxy)-rac-glycerol (12)—A flame dried flask was charged with $95 \% \mathrm{NaH}$ dispersion in oil $(0.159 \mathrm{~g}, 6.6 \mathrm{mmol})$ followed by 30 $\mathrm{mL}$ toluene and cooled to $0{ }^{\circ} \mathrm{C}$. A solution of $\mathbf{1 1}(1.51 \mathrm{~g}, 3.7 \mathrm{mmol})(25,26)$ in toluene $(30 \mathrm{~mL})$ was added via syringe and the mixture stirred for $1 \mathrm{~h}$. A solution of $5(2.1 \mathrm{~g}, 6.6 \mathrm{mmol})$ dissolved in $20 \mathrm{~mL}$ toluene was added at $25^{\circ} \mathrm{C}$ via syringe and the mixture heated at reflux overnight. Water $(50 \mathrm{~mL})$ was added and the aqueous phase extracted with diethyl ether $(3 \times 50 \mathrm{~mL})$, dried over $\mathrm{MgSO}_{4}$, filtered, and evaporated on a rotary evaporator. The crude product was purified by column chromatography using 10:1 hexane: $\mathrm{Et}_{2} \mathrm{O}$ as eluent. The fractions collected at $R_{\mathrm{f}}=0.2$ were pooled, evaporated, and the residue dried under vacuum to give $2.5 \mathrm{~g}$ of $\mathbf{1 2}$ (59\% yield) as a clear oil. ${ }^{1} \mathrm{H} \mathrm{NMR}\left(300 \mathrm{MHz}, \mathrm{CDCl}_{3}\right): 0.89\left(\mathrm{t}, 3 \mathrm{H},-\mathrm{CH}_{3}\right), 1.26(\mathrm{~s}, 50 \mathrm{H},-$ $\mathrm{CH}_{2}$ ), 1.57 (m, $4 \mathrm{H},-\mathrm{CH}_{2} \beta$ to O), 2.03 (c, $2 \mathrm{H}$, vinyl $\left.\mathrm{CH}_{2}\right), 3.45\left(\mathrm{~m}, 9 \mathrm{H},-\mathrm{OCH}_{2}\right), 4.56$ (s, 2 $\left.\mathrm{H},-\mathrm{OCH}_{2}-\mathrm{Ph}\right), 4.95\left(\mathrm{dd}, 2 \mathrm{H}\right.$, vinyl $\left.\mathrm{CH}_{2}\right), 7.33\left(\mathrm{~m}, 5 \mathrm{H},-\mathrm{C}_{6} \mathrm{H}_{5}\right) \cdot{ }^{13} \mathrm{C} \mathrm{NMR}(75 \mathrm{MHz}$, $\left.\mathrm{CDCl}_{3}\right)$ : 14.3, 22.9, 22.9, 26.3, 26.4, 26.4, 29.2, 29.4, 29.6, 29.7, 29.9, 30.3, 31.8, 32.2, 34.1, $70.5,70.8,71.0,71.2,71.9,73.6,78.2,114.3,127.7,127.8,128.5,138.7,139.5$. Mass $(\mathrm{M}+$ $\mathrm{H})=643$ by EI/CI.

\section{1,1'-Di-O-benzyl-2,2'-di-O-hexadecyl-3,3'-di-0-(16'-dotriacontenyl)-bis-} (racglycerol) (13)-This compound was prepared as described for 7 from 12. The crude product was purified via column chromatography using 7:2 hexane:diethyl ether. Fractions at $\mathrm{R}_{\mathrm{f}}=0.3$ were combined, evaporated, and the residue dried under vacuum to give $0.4007 \mathrm{~g}$ of 13 (91\% yield). ${ }^{1} \mathrm{H}$ NMR ( $\left.300 \mathrm{MHz}, \mathrm{CDCl}_{3}\right): 0.89\left(\mathrm{t}, 6 \mathrm{H},-\mathrm{CH}_{3}\right), 1.26\left(\mathrm{~s}, 25 \mathrm{H},-\mathrm{CH}_{2}\right), 1.57$ $\left(\mathrm{m}, 8 \mathrm{H},-\mathrm{CH}_{2} \beta\right.$ to O), $1.97\left(\mathrm{~m}, 4 \mathrm{H}\right.$, vinyl $\left.\mathrm{CH}_{2}\right), 3.43\left(\mathrm{~m}, 18 \mathrm{H},-\mathrm{OCH}_{2}\right), 4.56(\mathrm{~s}, 4 \mathrm{H},-$ $\left.\mathrm{OCH}_{2}-\mathrm{Ph}\right), 5.39\left(\mathrm{~m}, 2 \mathrm{H}\right.$, vinyl $\left.\mathrm{CH}_{2}\right), 7.33\left(\mathrm{~m}, 10 \mathrm{H},-\mathrm{C}_{6} \mathrm{H}_{5}\right) .{ }^{13} \mathrm{C} \mathrm{NMR}\left(75 \mathrm{MHz}, \mathrm{CDCl}_{3}\right)$ : 14.1, 22.7, 23.6, 26.1, 29.2, 29.4, 29.5, 29.7, 30.1, 31.9, 32.6, 70.3, 70.6, 70.7, 71.7, 73.3, 77.9, $127.5,127.6,128.3,130.3$. Mass $(\mathrm{M}+\mathrm{Na})=1279$ by MALDI. 
2,2'-Di-O-hexadecyl-3,3'-di-O-(dotriacontyl)-bis-(rac-glycerol) (14)-This compound was prepared as described for $\mathbf{8}$ starting from 13. The crude product was purified via column chromatography eluting with a gradient solvent system from 4:1 to 0:100 hexane: $\mathrm{Et}_{2} \mathrm{O}$, followed by a column flush with $5: 1 \mathrm{CHCl}_{3}: \mathrm{MeOH}$ to give $\mathbf{1 4}$ as a white solid (0.557 g, $90 \%$ yield). ${ }^{1} \mathrm{H}$ NMR ( $\left.300 \mathrm{MHz}, \mathrm{CDCl}_{3}\right): 0.89$ (t, $\left.6 \mathrm{H},-\mathrm{CH}_{3}\right), 1.25$ (s, $108 \mathrm{H}$, $\mathrm{CH}_{2}$ ), 1.56 (m, $8 \mathrm{H},-\mathrm{CH}_{2} \beta$ to O), 1.89 (bs, $\left.2 \mathrm{H},-\mathrm{OH}\right), 3.37-3.74$ (m, $18 \mathrm{H},-\mathrm{OCH}_{2}$, OCH). ${ }^{13} \mathrm{C}$ NMR (75 MHz, $\mathrm{CDCl}_{3}$ ): 14.1, 22.7, 26.1, 26.2, 29.2, 29.3, 29.5, 29.6, 29.7, 30.1, $31.9,63.0,70.4,70.9,71.8,78.3$. Mass $(\mathrm{M}+\mathrm{Na})=1102$ by MALDI.

\section{2,2'-Di-O-hexadecyl-3,3'-di-O-(dotriacontyl)-bis-(rac-glycerol)-1,1'-} diphosphocholine $\left(\mathrm{C}_{32} \mathrm{BAS}, 15\right)$-This compound was prepared as described for 9 using $\mathbf{1 4}$ as the precursor. The crude yellow solid obtained was purified via silica gel column chromatography using a step gradient elution with 80:20:0, 50:50:0, 0:100:0, 65:35:5, and 60:40:10 $\mathrm{CHCl}_{3}: \mathrm{MeOH}: \mathrm{H}_{2} \mathrm{O}$. The fractions containing product were combined and extracted using the Bligh-Dyer method. The organic phase was dried with $\mathrm{MgSO}_{4}$, concentrated and further dried under vacuum to give $0.0581 \mathrm{~g}$ of $\mathbf{1 5}$ (44\% yield); the remaining material was the starting diol, 14. ${ }^{1} \mathrm{H}$ NMR $\left(300 \mathrm{MHz}, \mathrm{CDCl}_{3}: \mathrm{CD}_{3} \mathrm{OD}\right): 0.89$ (t, $\left.6 \mathrm{H},-\mathrm{CH}_{3}\right), 1.28$ (s, $108 \mathrm{H}$, $\left.\mathrm{CH}_{2}\right), 1.57\left(\mathrm{t}, 8 \mathrm{H},-\mathrm{CH}_{2} \beta\right.$ to O), 3.23 (s, $\left.18 \mathrm{H}, \mathrm{N}\left(\mathrm{CH}_{3}\right)_{3}\right), 3.45-3.52\left(\mathrm{~m}, 6 \mathrm{H},-\mathrm{OCH}_{2},-\mathrm{OCH}\right)$, 3.58-3.64 (m, $\left.12 \mathrm{H},-\mathrm{OCH}_{2},-\mathrm{OCH}\right), 3.91$ (t, $4 \mathrm{H},-\mathrm{CH}_{2}-\mathrm{NMe}_{3}$ ), 4.29 (bs, $\left.4 \mathrm{H},-\mathrm{CH}_{2}-\mathrm{OP}\right) .{ }^{13} \mathrm{C}$ $\operatorname{NMR}\left(75 \mathrm{MHz}, \mathrm{CDCl}_{3}: \mathrm{CD}_{3} \mathrm{OD}\right): 24.4,27.8,31.1,31.3,31.4,31.8,33.6,55.9,72.4 .{ }^{31} \mathrm{P}$ NMR $\left(124 \mathrm{MHz}, \mathrm{CDCl}_{3}: \mathrm{CD}_{3} \mathrm{OD}\right)$ : one unreferenced peak. Mass $(\mathrm{M}+\mathrm{H})=1411$ by MALDI.

\section{DSC}

Calorimetric experiments were performed on a TA DSC-Q10 instrument using $1 \mathrm{mg}$ lipid/4 $\mathrm{mg} \mathrm{H}_{2} \mathrm{O}$ in stainless steel pans. All thermograms were run using a reference pan with $\mathrm{H}_{2} \mathrm{O}$. Indium was used as a calibration standard. Thermograms were collected in the heating mode using a scan rate of $1{ }^{\circ} \mathrm{C} / \mathrm{min}$. The temperatures scanned ranged from -20 to $85^{\circ} \mathrm{C}$. Three thermograms were collected and the average values for the transition temperature (determined at the transition peak) reported.

\section{P NMR chemical shift anisotropy}

Proton-decoupled ${ }^{31} \mathrm{P}$ NMR spectra were acquired at temperatures from -5 to $30^{\circ} \mathrm{C}$ to determine the change in chemical shift anisotropy of the ${ }^{31} \mathrm{P}$ powder pattern lineshape for $\mathrm{C}_{32}$ phytBAS. The sample was prepared by hydrating a dry film of $\mathrm{C}_{32}$ phytBAS at a concentration of $20 \mathrm{mg} / \mathrm{mL}$ in $\mathrm{D}_{2} \mathrm{O}$. Spectra were obtained using a Bruker DRX 500 spectrometer equipped with a $5 \mathrm{~mm}$ probe. A period of $15 \mathrm{~min}$ was allowed for temperature equilibration before spectral acquisition at each temperature studied. All spectra were acquired using the following parameters: 1600 scans, relaxation delay of $1 \mathrm{sec}, 90^{\circ}$ pulse duration of 6 $\mu \mathrm{sec}$, acquisition time of $0.2 \mathrm{sec}$, and $200 \mathrm{~Hz}$ line broadening. The peak width at half the peak height was measured for each spectrum and the results plotted in ppm vs. temperature. The intersection of the two linear regions in this plot was taken as the $\mathrm{T}_{\mathrm{m}}$.

\section{FRAP}

Standard coverslips were cleaned with warm 7:1 Triton ${ }^{\circledR} \mathrm{X} 100: \mathrm{H}_{2} \mathrm{O}$ for $10 \mathrm{~min}$, rinsed extensively with deionized $\mathrm{H}_{2} \mathrm{O}$, dried under a stream of $\mathrm{N}_{2}$ and baked at $400{ }^{\circ} \mathrm{C}$ for $5 \mathrm{~h}$. Vesicles of POPC, POPC: $\mathrm{C}_{20}$ BAS (100 nm nominal diameter), $\mathrm{C}_{20} \mathrm{BAS}$, and $\mathrm{C}_{32}$ phytBAS (200 nm nominal diameter) were prepared by extrusion as described below, except that 18 $\mathrm{M} \Omega \mathrm{H}_{2} \mathrm{O}$ was used instead of buffer and the extrusions were done at $65^{\circ} \mathrm{C}$. Total lipid concentrations were $5 \mu \mathrm{mol} / \mathrm{mL}$ at lipid ratios of $99.5 \% \mathrm{lipid}+0.5 \% \mathrm{NBD}-\mathrm{OPPC}$. The vesicle solutions were mixed with $300 \mathrm{mM} \mathrm{NaCl}(1: 1 \mathrm{vol} / \mathrm{vol})$ and transferred to a perfusion chamber mounted on the coverslips. After approximately $1 \mathrm{~min}$, the coverslips were dipped into a 18 
$\mathrm{M} \Omega \mathrm{H}_{2} \mathrm{O}$ bath and a cover glass sandwich prepared. The sandwich was quickly placed on a microscope holder with $\mathrm{H}_{2} \mathrm{O}$ pools on both sides. A detailed description of this method for preparing supported lipid bilayers from vesicles has been reported elsewhere $(28,29)$.

A Nikon TE200U fluorescence microscope coupled to a silicon avalanche photodiode and a continuous wave argon ion laser ( $488 \mathrm{~nm}$ emission, $25 \mathrm{~mW}$ ) was used to both bleach and excite the NBD-OPPC probe $\left(\lambda_{\mathrm{ex}}=460 \mathrm{~nm}, \lambda_{\mathrm{em}}=534 \mathrm{~nm}\right)$. A neutral density filter was placed in the beam path to reduce the laser intensity to $250 \mathrm{nW}$ to avoid constant photobleaching of the probe. A shutter in the beam path was pulsed to enable detection of the initial fluorescence counts for $\sim 40 \mathrm{~s}$. Upon removal of the filter from the beam path, the shutter sends a single photobleaching laser pulse for $\leq 1 \mathrm{~s}$ (bleach radius $=13 \mu \mathrm{m}$ ). The recovery of fluorescence intensity in this photobleached area is then monitored as a function of time. Diffusion coefficients of NBD-OPPC in various membrane compositions were determined by measuring the half-time to recovery using a modified Bessel function as described by Soumpasis (30). All of the data were fit as a single exponential and compared to POPC as standard. Diffusion coefficients determined in this manner are accurate to $\pm 15 \%$. All FRAP measurements were conducted at $25^{\circ} \mathrm{C}$.

\section{Vesicle Preparation}

Dry lipid $(10 \mathrm{mg})$ was dissolved in $1: 1 \mathrm{CHCl}_{3}: \mathrm{MeOH}$ in a cryovial and a thin film produced from it by evaporating the solvent under a gentle stream of Ar. The solvent was further removed under a $100 \mu \mathrm{m}$ vacuum overnight. After addition of $1 \mathrm{~mL} 100 \mathrm{mM}$ TRIS $\mathrm{HCl} \mathrm{pH} \mathrm{7.5,} \mathrm{the}$ solution was subjected to five cycles of freeze (liquid $\mathrm{N}_{2}$ bath), thaw (water bath at $35^{\circ} \mathrm{C}$ for $5 \mathrm{~min}$ ), and vortex (30 s) to give a polydisperse MLV suspension as described by DiMeglio et al. (31). This dispersion was extruded twenty times at $25^{\circ} \mathrm{C}$ through two stacked $100 \mathrm{~nm}$ pore track-etch filters to produce an almost transparent solution. All samples were prepared similarly and were analyzed immediately after preparation.

\section{Purification of Ste14p from Membranes}

Ste $14 \mathrm{p}$ with ten histidine residues and three repeats of the myc epitope at the $\mathrm{N}$-terminus was expressed and purified as previously described (20). The histidines were used to facilitate Ste $14 \mathrm{p}$ purification and the myc epitopes were used for immunodetection. Briefly, $\mathrm{His}_{10}{ }_{10} c_{3}$-tagged Ste14p was expressed in S. cerevisiae, extracted from crude membranes using $1 \%$ (w:v) 1- $\beta$-D-dodecylmaltopyranoside (DDM), and purified using Talon ${ }^{\mathrm{TM}}$ metal affinity chromatography. The activity of the pure enzyme was measured using AFC as the model substrate in an in vitro vapor diffusion methyltransferase assay (see below). Protein concentrations were determined by an amido black protein assay (32).

\section{Reconstitution of Ste14p in Mixed Lipid Vesicles}

Purified Ste14p was reconstituted by rapid dilution in the presence of lipid dispersions as previously described (20). Briefly, $\sim 1 \mu \mathrm{g}$ of protein was added to $10 \mu \mathrm{L}$ of a $10 \mathrm{mg} / \mathrm{mL}$ vesicle solution and a subsequent 20 -fold rapid dilution was performed by addition of $100 \mathrm{mM}$ Tris$\mathrm{HCl} \mathrm{pH} 7.5$ buffer at $5{ }^{\circ} \mathrm{C}$.

\section{In Vitro Vapor Diffusion Methyltransferase Assay}

The assay was performed as previously described by Anderson et al. (20) with the exception that the reactions contained less than $0.9 \mu \mathrm{g}$ of purified protein. The buffer, vesicle solution, protein and assay reagents were temperature-equilibrated on ice prior to the addition of $1 \mu \mathrm{g}$ Ste $14 \mathrm{p}$ to $10 \mu \mathrm{L}$ of vesicle solution followed by addition of $200 \mu \mathrm{M}$ AFC. The samples were incubated on ice for 5 minutes followed by rapid dilution with buffer and the addition of 20 $\mu \mathrm{M}\left[{ }^{14} \mathrm{C}\right]-\mathrm{SAM}$ to a final volume of $60 \mu \mathrm{L}$. The reaction solution was incubated in a water 
bath at $30^{\circ} \mathrm{C}$ and the reaction allowed to progress for $30 \mathrm{~min}$. The methyl transfer reaction was quenched by the addition of $50 \mu \mathrm{L}$ of $1 \mathrm{M} \mathrm{NaOH} / 1 \%$ SDS. The mixture $(100 \mu \mathrm{L})$ was then spotted on filter paper and placed in the neck of a scintillation vial that contained $10 \mathrm{~mL}$ BioSafe II scintillation cocktail. After $2.5 \mathrm{~h}$, the filters were removed and the $\mathrm{NaOH}$-labile counts determined by liquid scintillation. The results are reported in pmol of methyl groups transferred/mg protein/min of reaction.

\section{Temperature-Dependent Methyltransferase Assays}

In vitro vapor diffusion methyltransferase assays were performed at different temperatures to test the effect of the lipid phase transition temperature on protein activity. Ste14p was reconstituted at $32^{\circ} \mathrm{C}$ into $E$. coli polar lipid, DMPC and $\mathrm{C}_{20} \mathrm{BAS}$ liposomes. In vitro vapor diffusion methyltransferase experiments were done as previously described with the exception that the incubation temperature was changed to $10^{\circ} \mathrm{C}, 16^{\circ} \mathrm{C}, 32^{\circ} \mathrm{C}$, or $44^{\circ} \mathrm{C}$ as needed to probe Ste $14 \mathrm{p}$ activity above and below the phase transition temperature of the host membrane.

\section{Confocal Immunofluorescence Microscopy}

Ste $14 \mathrm{p}$ ( $10 \mu \mathrm{L}$ of a $0.012 \mu \mathrm{g} / \mu \mathrm{L}$ in $500 \mathrm{mM}$ imidazole elution buffer) was diluted to a final volume of $200 \mu \mathrm{L}$ in $100 \mathrm{mM}$ Tris- $\mathrm{HCl} \mathrm{pH} 7.5$ buffer containing unextruded vesicles ( $1 \mu \mathrm{L}$ of a $10 \mu \mathrm{g} / \mu \mathrm{L}$ ). The protein was stained by the addition of an anti-myc monoclonal mouse antibody followed by the addition of a fluorescein isothiocyanate-conjugated goat-anti mouse secondary antibody $(0.1 \mu \mathrm{L}$ of $1 \mu \mathrm{g} / \mu \mathrm{L})$. Nile Blue was then added to stain the membrane and the samples were imaged at $60 \times$ magnification.

\section{RESULTS}

\section{Synthesis}

$\mathrm{C}_{32}$ phytBAS was prepared as shown in Scheme 2 based on the previously described syntheses of $\mathrm{C}_{20} \mathrm{BAS}$ and $\mathrm{C}_{32} \mathrm{BAS}$ (24-26). Phytanyl iodide, prepared by iodination of phytol in the presence of triphenylphosphine and imidazole, was coupled with 2-phenyl-5-hydroxy-1,3dioxane to produce ether $\mathbf{2}$ in quantitative yield. The phytanyl olefin was hydrogenated in the presence of Wilkinson's catalyst in $85 \%$ yield. Reductive ring opening of the dioxane ring with DIBAL-H (33) gave the 2-phytanyl-1-benzyl-rac-glycerol diether 4 in 89\% yield. Alkylation of the primary alcohol in $\mathbf{4}$ with $\mathbf{5}$ (27) gave the corresponding benzyl-protected glyceryl triether $\mathbf{6}$ in 29\% yield. Dimerization of $\mathbf{6}$ via olefin metathesis using the first-generation Grubbs catalyst (34) gave 7 in $62 \%$ yield. Simultaneous olefin reduction and deprotection of 7 was achieved using $\mathrm{Pd}(\mathrm{OH})_{2}$-catalyzed hydrogenolysis. The phosphocholine headgroup was installed in the final step using a 2-chloro-2-oxo-1,3,2-dioxaphospholane esterification/ trimethylamine ring opening sequence $(35,36)$, to give the methyl substituted bolalipid, $\mathrm{C}_{32}-$ phytBAS (9) in $81 \%$ yield ( $2 \%$ overall yield).

The synthesis route for $\mathrm{C}_{32} \mathrm{BAS}$ (Scheme 3) followed a similar path. 2-Phenyl-5hexadecyloxy-1,3-dioxane (10), prepared as described by Patwardhan and Thompson $(25,26)$ in 79\% yield, was subjected to reductive ring opening with DIBAL-H (33) to give $\mathbf{1 1}$ in 84\% yield. 17-Bromo-1-heptadecene (5) was used to alkylate $\mathbf{1 1}$ in 59\% yield. Intermediate $\mathbf{1 3}$ was obtained in $91 \%$ yield via dimerization of $\mathbf{1 2}$ using Grubbs catalyst (34). Simultaneous deprotection and reduction of this precursor gave the tetraether bisglycerol intermediate 14 in $90 \%$ yield. Installation of the phosphocholine headgroups as before produced $\mathrm{C}_{32} \mathrm{BAS}(\mathbf{1 5})$ in $44 \%$ yield ( $14 \%$ overall yield). 


\section{Phase transition behavior of $\mathrm{C}_{32}$ phytBAS and $\mathrm{C}_{32} \mathrm{BAS}$ dispersions}

The DSC data obtained for hydrated $\mathrm{C}_{32}$ phytBAS, $\mathrm{C}_{20} \mathrm{BAS}$, and $\mathrm{C}_{32} \mathrm{BAS}$ in sealed pans is summarized in Table 1 . The $\mathrm{C}_{20} \mathrm{BAS}$ was previously reported to have a $\mathrm{T}_{\mathrm{m}}=17^{\circ} \mathrm{C}$ as determined by DSC and temperature-dependent Raman spectroscopy (31). DSC experiments revealed that the gel-to-liquid crystalline phase transition of $\mathrm{C}_{32}$ phytBAS was $14{ }^{\circ} \mathrm{C}$ (Figure $2 \mathrm{~A}$ ) and was undetectable up to $85^{\circ} \mathrm{C}$ for $\mathrm{C}_{32} \mathrm{BAS}$ (data not shown). Changes in the chemical shift anisotropy of $\mathrm{C}_{32}$ phytBAS, determined by temperature-dependent ${ }^{31} \mathrm{P}$ NMR (Figure 2B), also indicated that the $\mathrm{T}_{\mathrm{m}}$ for this bolalipid was $14^{\circ} \mathrm{C}$.

\section{Lateral diffusion rates of $\mathrm{C}_{32}$ phytBAS dispersions}

Work by Thompson and coworkers (37) has shown that the lateral diffusion coefficients for POPC, $\mathrm{C}_{20} \mathrm{BAS}: \mathrm{POPC}, \mathrm{C}_{20} \mathrm{BAS}$, and 7:3 $\mathrm{C}_{20} \mathrm{BAS}$ : $\mathrm{Chol}$ on detergent cleaned and baked cover glass are $8 \times 10^{-8} \mathrm{~cm}^{2} / \mathrm{s}, 4 \times 10^{-8} \mathrm{~cm}^{2} / \mathrm{s}, 1.5 \times 10^{-8} \mathrm{~cm}^{2} / \mathrm{s}$, and $1.2 \times 10^{-9} \mathrm{~cm}^{2} / \mathrm{s}$, respectively. Our FRAP data for glass-supported bolalipid membranes showed that the lateral diffusion rate of pure $\mathrm{C}_{32}$ phytBAS $\left(1.8 \times 10^{-9} \mathrm{~cm}^{2} / \mathrm{s}\right.$, Table 2$)$ was an order of magnitude slower than that observed for the unbranched shorter chain variant, $\mathrm{C}_{20} \mathrm{BAS}\left(1.5 \times 10^{-8} \mathrm{~cm}^{2} / \mathrm{s}\right.$, Table 2$)$ and similar to that observed for 7:3 $\mathrm{C}_{20} \mathrm{BAS}$ : Chol $\left(1.2 \times 10^{-9} \mathrm{~cm}^{2} / \mathrm{s}\right.$, Table 2$)$.

\section{In vitro vapor diffusion methyltransferase assays}

In vitro vapor diffusion methyltransferase assays (Scheme 4) demonstrated that when the molar ratio of $\mathrm{C}_{20} \mathrm{BAS}$ was increased in E. coli polar lipid membranes, Ste $14 \mathrm{p}$ activity was retained until the $\mathrm{C}_{20} \mathrm{BAS}$ content in the membrane exceeded $50 \mathrm{~mol} \%$ (Figure 3A). At 3:1

$\mathrm{C}_{20} \mathrm{BAS}$ :E. coli polar lipid, only $15 \%$ methyltransferase activity remained, whereas only $3 \%$ activity remained in pure $\mathrm{C}_{20} \mathrm{BAS}$. A similar variation of membrane composition using $\mathrm{C}_{32}$ phytBAS showed that Ste $14 \mathrm{p}$ activity was retained in all molar ratios tested, such that pure $\mathrm{C}_{32}$ phytBAS vesicles possessed $80 \%$ of the Ste $14 p$ methyltransferase activity found in Ste $14 p$ vesicles reconstituted with pure $E$. coli polar lipid extract.

When POPC was used as the host membrane lipid instead of E. coli polar lipid, the Ste $14 \mathrm{p}$ activity dropped to $47 \%$ of its level in $100 \%$ E. coli polar lipid (Figure 3B). Ste $14 p$ activity gradually dropped as the $\mathrm{C}_{20} \mathrm{BAS}$ composition in POPC increased to 1:1 $\mathrm{C}_{20} \mathrm{BAS}: \mathrm{POPC}$. Further increases in the $\mathrm{C}_{20} \mathrm{BAS}$ molar ratio, however, caused a drop in the methyltransferase activity to $16 \%$ and $4 \%$ of the pure POPC level for $3: 1$ and $100: 0 \mathrm{C}_{20} \mathrm{BAS}: \mathrm{POPC}$ compositions, respectively. When the same bolalipid composition variation experiment was performed with $\mathrm{C}_{32}$ phytBAS in POPC, Ste14p activity was retained at levels similar or greater than that of pure POPC dispersions regardless of $\mathrm{C}_{32}$ phytBAS content in the membrane. It should be noted that the slight difference in Ste14p specific activity observed in both $100 \% \mathrm{C}_{32}$ phytBAS dispersions (Figures $3 \mathrm{~A} \& \mathrm{~B}$ ) is due to the different Ste14p preparations used in these two series of experiments. Nonetheless, all bolalipid:E. coli polar lipid data were collected with a single Ste $14 p$ preparation, whereas all bolalipid:POPC data were collected with another Ste14 preparation to eliminate this difference as a variable within a set of lipid mixtures.

To further probe the influences of lipid physical properties on Ste14p function, we monitored its methyltransferase activity in lipids above and below their gel to liquid crystalline phase transition after reconstitution at a single temperature $\left(32^{\circ} \mathrm{C}\right)$ (Table 3). For E. coli polar lipid (control), Ste14p activity remained essentially constant when the assay temperature was maintained at $10,16,32$, or $44^{\circ} \mathrm{C}$. The methyltransferase activity in DMPC was unchanged below $\left(16^{\circ} \mathrm{C}\right)$ and above $\left(32^{\circ} \mathrm{C}\right)$ its phase transition temperature $\left(\mathrm{T}_{\mathrm{m}}=23^{\circ} \mathrm{C}\right)$, yielding activity levels that were the same as the $E$. coli polar lipid values within experimental error. Dramatically different behavior was found for $\mathrm{C}_{20} \mathrm{BAS}$, however. In this case, the methyltransferase activity was only $5 \%$ of that observed for E. coli polar lipid above $\left(32{ }^{\circ} \mathrm{C}\right)$ and below $\left(10^{\circ} \mathrm{C}\right)$ the phase transition temperature of $\mathrm{C}_{20} \mathrm{BAS}\left(\mathrm{T}_{\mathrm{m}}=17^{\circ} \mathrm{C}\right)$. 
Confocal immunofluorescence assays were performed to determine whether Ste14p was actually incorporated within the membrane dispersions where low methyltransferase activity was observed (Figure 4). Fluorescence and phase contrast images were collected on reconstituted vesicle samples prepared as described above, except that mouse anti-myc primary antibodies and FITC-labeled goat anti-mouse secondary antibodies were added to fluorescently-label Ste14p and Nile Blue was added as a membrane-localizing fluorophore. As the data in Figure 4 demonstrate, Ste14p was present in all reconstituted vesicle compositions, including those showing low methyltransferase activity (i.e., $\mathrm{C}_{20} \mathrm{BAS}$ ).

\section{DISCUSSION}

The goal of this study was to determine the optimal host membrane material in which to functionally reconstitute the Icmt enzyme, Ste14p, for use in a stable supported membrane sensor. The design rules for producing stable integral membrane protein-containing membranes are not yet clear. For example, some integral membrane protein enzymes, such as $\mathrm{Ca}^{2+}$-ATPase, do not retain their functional conformation in gel phase lipid bilayers (38). However, not all membrane proteins display higher activities in the liquid-crystalline phase membranes, particularly when the liquid crystalline membrane phase is too thin to accommodate the entire hydrophobic surface of the protein. This is the case with diacylglycerol kinase and $\mathrm{Na}^{+}, \mathrm{K}^{+}$-ATPase $(39,40)$, both of which undergo activity enhancements when the host membrane thickens upon transition from the liquid crystalline to gel phase. In some other cases, the proteins themselves affect the transition temperature of the surrounding lipids to relieve hydrophobic mismatch between the membrane and the integral membrane protein (41). The function of bacteriorhodopsin (bR)-containing membranes, however, is highly dependent on membrane fluidity. $\mathrm{bR}$ in polymerized synthetic bilayer membranes is inactive $(42,43)$, while bR in bilayers composed of naturally-occurring lipids shows a strong dependence on the site and degree of acyl chain unsaturation (44). Taken together, these studies show that integral membrane protein activity can be strongly influenced in unpredictable ways by the phase behavior, physical dimensions and fluidity of the host membrane.

An existing bolalipid, $\mathrm{C}_{20} \mathrm{BAS}$, and two newly synthesized bolalipids, $\mathrm{C}_{32} \mathrm{BAS}$ and $\mathrm{C}_{32}$ phytBAS (prepared in $14 \%$ and $2 \%$ overall yield, respectively), were used to probe the structure-performance relationship between bolalipid structure and Ste14p activity. DSC and ${ }^{31} \mathrm{P}$ NMR data show that $\mathrm{C}_{32}$ phytBAS and $\mathrm{C}_{20} \mathrm{BAS}$ form liquid crystalline membranes at $25^{\circ} \mathrm{C}$, however, $\mathrm{C}_{32} \mathrm{BAS}$ is in the gel phase at this temperature and did not have an observable melting transition over the temperature range studied $\left(15-85^{\circ} \mathrm{C}\right)$. Methyl branching of the $s n-2$ chains in $\mathrm{C}_{32}$ phytBAS disrupts the alkyl chain packing of this bolalipid, thereby increasing membrane fluidity and lowering the gel to liquid crystalline phase transition temperature and the transition enthalpy relative to $\mathrm{C}_{32} \mathrm{BAS}$. The observed phase transition temperature of $\mathrm{C}_{32}$ phytBAS, $\mathrm{T}_{\mathrm{m}}=14{ }^{\circ} \mathrm{C}$, is in reasonable agreement with the value of $8{ }^{\circ} \mathrm{C}$ reported by Kinoshita and co-workers, who also prepared this bolalipid $(45,46)$. Differences in sample preparation methods, the presence of contaminants, or different thermal history of the samples may account for the lower temperature reported in the previous work. The $\mathrm{T}_{\mathrm{m}}$ of $\mathrm{C}_{20} \mathrm{BAS}$ has been previously reported to be $17^{\circ} \mathrm{C}(31,37)$. The absence of methyl branching in $\mathrm{C}_{20} \mathrm{BAS}$ and the shorter membrane-spanning alkyl chain length $\left(\mathrm{C}_{20}\right.$ vs. $\left.\mathrm{C}_{32}\right)$ are factors that compensate each other to produce a bolalipid with a modest phase transition temperature in this case. The $\mathrm{T}_{\mathrm{m}}$ values measured for this bolalipid series are summarized in Table 1.

Lateral diffusion rates of the liquid-crystalline bolalipids, determined using the FRAP technique for supported membrane samples, are summarized in Table 2 along with the control lipid, POPC. The diffusion rate obtained for $\mathrm{C}_{20} \mathrm{BAS}$ was slower by a factor of five relative to POPC under the same conditions. When $30 \mathrm{~mol} \% \mathrm{Chol}$ was incorporated in the $\mathrm{C}_{20} \mathrm{BAS}$ membrane, the observed lateral diffusion rate decreased by an order of magnitude, giving a 
value similar to that obtained for the longer chain $\mathrm{C}_{32}$ phytBAS derivative. FRAP measurements were not possible with $\mathrm{C}_{32} \mathrm{BAS}$. This bolalipid produced glass-supported membranes where only punctate fluorescence was observed, indicative of fluorphore-rich domains that were phase separated from the gel phase bolalipid. We infer from these results that the reduced rates of diffusion in bolalipid membranes, relative to monopolar lipids that form bilayer membranes, is caused by coupled diffusion of headgroups at opposing lipid-water interfaces in the monolayer membranes formed by bolalipids (Figure 5). An alternative explanation is based on the consideration of lipid size. Since methyl branching increases the lipid molecular area at the lipid-water interface relative to its unbranched counterpart (45), the diffusion path length of these larger diameter molecules is effectively increased, thereby decreasing the net diffusion rate. Our observed diffusion rate of $1.8 \times 10^{-9} \mathrm{~cm}^{2} / \mathrm{s}$ for $\mathrm{C}_{32}$ phytBAS is in reasonable agreement with the reported value of $7 \times 10^{-9} \mathrm{~cm}^{2} / \mathrm{s}$ for a biogenic bolalipid extract (9:1 bolalipid:monopolar lipid), determined at $30^{\circ} \mathrm{C}$ by $2 \mathrm{D}$ exchange ${ }^{31} \mathrm{P}$ NMR (47). A key finding from these experiments is that the slower bolalipid lateral diffusion rates did not significantly impact methyltransferase activity in the functional reconstitution of Ste $14 p$ within bolalipid vesicles. While there is no literature on this subject as far as we know, we anticipated that a change in lipid lateral diffusion rate would lead to changes in membrane microviscosity that would ultimately impact Ste $14 \mathrm{p}$ activity. Our data suggest that Ste14p may not be sensitive to these types of membrane perturbations.

Confocal immunofluorescence microscopy further shows that the properties of the lipid do not alter the capacity for Ste $14 p$ incorporation within the host membrane (i.e., Ste $14 p$ is incorporated within both gel and liquid crystalline phase membranes as well as hydrophobically-mismatched membranes). Consistent with this finding, protein assay results confirmed the presence of Ste14p in the membrane, regardless of lipid type. Since the hydrated membrane thicknesses for $\mathrm{C}_{20} \mathrm{BAS}, \mathrm{C}_{32} \mathrm{BAS}$, and $\mathrm{C}_{32}$ phytBAS are $32 \AA$ ( 31$), 56 \AA$ and $50 \AA$, respectively, we conclude that the lower levels of methytransferase activity observed in $\mathrm{C}_{20} \mathrm{BAS}$ vesicles is caused by mismatch of the hydrophobic domain of Ste $14 \mathrm{p}$ (anticipated to be on the order of $40 \AA$ thick) and the $\sim 28 \AA$ thick hydrophobic region of the $\mathrm{C}_{20} \mathrm{BAS}$ membrane (Figure 6). This hydrophobic mismatch may lead to misfolded and/or denatured Ste14p segments in the thinner $\mathrm{C}_{20} \mathrm{BAS}$ membranes, thereby accounting for the lower methyltransferase activity observed.

\section{CONCLUSIONS}

Hrycyna and co-workers (20) have previously shown that Ste14p can be reconstituted in vesicles with a variety of different monopolar lipid types while retaining greater than $60 \%$ of the activity present in E. coli polar lipid extract vesicles. We now report that a large amount of Ste $14 \mathrm{p}$ activity was retained (65\% or higher) in membranes composed of $\leq 50 \mathrm{~mol} \%$ $\mathrm{C}_{20} \mathrm{BAS}$, however, methyltransferase activity decreases rapidly at higher molar ratios of $\mathrm{C}_{20}$ BAS. Ste $14 \mathrm{p}$ activity levels were maintained across the full 0-100 mol\% range of $\mathrm{C}_{32}$ phytBAS:E. coli polar lipid extract compositions. Surprisingly, gel phase lipids do not appear to negatively affect methyltransferase activity, based on our findings that gel phase lipids (DMPC vesicles at $16^{\circ} \mathrm{C}$ ) and liquid crystalline phase lipids $\left(\mathrm{C}_{32}\right.$ phytBAS and DMPC vesicles at $25^{\circ} \mathrm{C}$ and $32{ }^{\circ} \mathrm{C}$, respectively) yield similar activities at membrane compositions of $\leq 50 \mathrm{~mol} \%$ bolalipid. The thickness of the hydrophobic region of the membrane, however, does appear to have a significant impact on Ste $14 \mathrm{p}$ activity, with the thinner $\mathrm{C}_{20} \mathrm{BAS}$ membrane producing a less active reconstituted Ste $14 \mathrm{p}$ vesicle dispersion. Additional experiments to probe this question and extension of these studies to other classes of integral membrane proteins are in progress to determine the generality of these findings. 


\section{Supplementary Material}

Refer to Web version on PubMed Central for supplementary material.

\section{ABBREVIATIONS}

AFC, $N$-acetyl- $S$-farnesyl-L-cysteine

${ }^{14} \mathrm{C}$-SAM, $S$-adenosyl-L- $\left[{ }^{14} \mathrm{C}\right.$-methyl] methionine

$\mathrm{C}_{20} \mathrm{BAS}, 2,2$ '-di-O-decyl-3,3'-di-O-(1",20”-eicosanyl)-bis-(rac-glycero)-1,1'diphosphocholine

$\mathrm{C}_{32}$ BAS, 2,2'-di-O-hexadecyl-3,3'-di-O-(1",32'-dotriacontanyl)-bis-(rac-glycero)-1,1'diphosphocholine

$\mathrm{C}_{32}$ phytBAS, 2,2'-di-O-(3,7,11,15-tetramethylhexadecyl)-3,3'-di-O-(1",32'-dotriacontanyl)-

bis-(rac-glycero)-1,1'-diphosphocholine

Chol, cholesterol

DDM, 1-dodecyl- $\beta$-D-maltopyranoside

DMF, $N, N$-dimethylformamide

DMPC, 1,2-dimyristoyl-sn-glycero-3-phosphocholine

DSC, differential scanning calorimetry

E. coli polar lipid, commercial polar lipid extract from E. coli

FRAP, fluorescence recovery after photobleaching

Ste14p, His $_{10}$ myc $_{3}$-tagged Ste14p Icmt isolated from S. cerevisiae

Icmt, isoprenylcysteine carboxyl methyltransferase

NBD-OPPC, 1-oleoyl-2-[6-[(7-nitro-2-1,3-benzoxadiazol-4-yl)amino]hexanoyl]-sn-

glycero-3-phosphocholine

POPC, 1-palmitoyl-2-oleoyl-sn-glycero-3-phosphocholine

SDS, sodium dodecylsulfate

THF, tetrahydrofuran

Tris, tris(hydroxymethyl)aminomethane

\section{ACKNOWLEDGEMENTS}

The authors would like to acknowledge the assistance of Dr. Jong-Mok Kim (bolalipid preparation), Kalani Seu and Prof. Jennifer Hovis (FRAP measurements), Prof. Richard Gibbs (AFC substrate), and Jennifer Sturgis (confocal microscopy).

\section{REFERENCES}

1. Langworthy, TA. The Bacteria Vol. VIII. Woese, CR.; Wolfe, RS., editors. New York: Academic Press; 1985. p. 459-497.

2. Damsté JSS, Schouten S, Hopmans EC, van Duin ACT, Geenevasen JAJ. Crenarchaeol: the characteristic core glycerol dibiphytanyl glycerol tetraether membrane lipid of cosmopolitan pelagic crenarchaeota. J. Lipid Res 2002;43:1641-1651. [PubMed: 12364548]

3. De Rosa M, Gambacorta A. The lipids of archaebacteria. Prog. Lipid Res 1988;27:153-175. [PubMed: 3151021]

4. Kates M. Adventures with membrane lipids. Biochem. Soc. Trans 1995;23:697-709. [PubMed: 8654821]

5. Patel GB, Sprott GD. Archaeobacterial ether lipid liposomes (archaeosomes) as novel vaccine and drug delivery systems. Crit. Rev. Biotech 1999;19:317-357.

6. Gräther O, Arigoni D. Detection of regioisomeric macrocyclic tetraethers in the lipids of methanobacterium-thermoautotrophicum and other archaeal organisms. Chem. Comm 1995;4:405406. 
7. Hopmans EC, Schouten S, Pancost RD, van der Meer MTJ, Damsté JSS. Analysis of intact tetraether lipids in archaeal cell material and sediments by high performance liquid chromatography/atmospheric pressure chemical ionization mass spectrometry. Rapid Comm. Mass Spec 2000;14:585-589.

8. Thompson DH, Wong K, Humphry-Baker R, Wheeler J, Kim J-M, Rananavare SB. Tetrather bolaform amphiphiles as models of archaebacterial membrane-lipids -Raman-spectroscopy, P-31 NMR, X-Ray scattering, and electron-microscopy. J. Am. Chem. Soc 1992;114:9035-9042.

9. Elferink MGL, de Wit JG, Driessen AJM, Konings WN. Stability and proton-permeability of liposomes composed of archaeal tetraether lipids. Biochim. Biophys. Acta 1994;1193:247-254. [PubMed: 8054346]

10. Arakawa K, Kano H, Eguchi T, Nishiyama Y, Kakinuma K. Significance of the 72-membered macrocyclic structure found in archaeal membrane lipids: Model studies of the macrocyclic tetraether diphospholipids by calorimetric, P-31 NMR, and electron microscopic analyses. Bull. Chem. Soc. Jpn 1999;72:1575-1581.

11. Arakawa K, Eguchi T, Kakinuma K. Highly thermostable liposome from 72-membered macrocyclic tetraether lipid: Importance of 72-membered lipid for archaea to thrive under hyperthermal environments. Chem. Lett 2001;5:440-441.

12. Kim J-M, Patwardhan A, Bott A, Thompson DH. Preparation and electrochemical behavior of gramicidin-bipolar lipid monolayer membranes supported on gold electrodes. Biochim. Biophys. Acta 2003;1617:10-21. [PubMed: 14637015]

13. Thompson DH, Patwardhan AP, Di Meglio C, Kim J-M, Haynes R, Burden DL, Rananavare SB. unpublished results.

14. Cornell BA, Braach-Maksvytis VLB, King LG, Osman PDJ, Raguse B, Wieczorek L, Pace RJ. A biosensor that uses ion-channel switches. Nature 1997;387:580-583. [PubMed: 9177344]

15. Wiess-Wichert C, Smetazko M, Valina-Saba M, Schalkhammer T. A new analytical device based on gated ion channels: A peptide-channel biosensor. J. Biomol. Screening 1997;2:11-18.

16. Elferink MGL, de Wit JG, Demel R, Driessen AJM, Konings WN. Functional reconstitution of membrane-proteins in monolayer liposomes from bipolar lipids of Sulfolobus acidocaldarius. J. Biol. Chem 1992;267:1375-1381. [PubMed: 1309769]

17. In't Veld G, Elferink MGL, Driessen AJM, Konings WN. Reconstitution of the leucine transportsystem of Lactococcus lactis into liposomes composed of membrane-spanning lipids from Sulfolobus acidocaldarius. Biochemistry 1992;31:12493-12499. [PubMed: 1463735]

18. Romano JD, Michaelis S. Topological and mutational analysis of Saccharomyces cerevisiae Ste14p, founding member of the isoprenylcysteine carboxyl methyltransferase family. Mol. Biol. Cell 2001;12:1957-1971. [PubMed: 11451995]

19. Dai Q, Choy E, Chiu V, Romano J, Slivka SR, Steitz SA, Michaelis S, Philips MR. Mammalian prenylcysteine carboxyl methyltransferase is in the endoplasmic reticulum. J. Biol. Chem 1998;273:15030-15034. [PubMed: 9614111]

20. Anderson JL, Frase H, Michaelis S, Hrycyna CA. Purification, functional reconstitution, and characterization of the Saccharomyces cerevisiae isoprenylcysteine carboxylmethyltransferase Ste14p. J. Biol. Chem 2005;280:7336-7345. [PubMed: 15611058]

21. Pillinger MH, Volker C, Stock JB, Weissmann G, Philips MR. Characterization of a plasma membrane-associated prenylcysteine-directed alpha carboxyl methyltransferase in human neutrophils. J Biol Chem 1994;269:1486-1492. [PubMed: 8288614]

22. Stephenson RC, Clarke S. Characterization of a rat liver protein carboxyl methyltransferase involved in the maturation of proteins with the -CXXX C-terminal sequence motif. J. Biol. Chem 1992;267:13314-13319. [PubMed: 1320016]

23. Boivin D, Gingras D, Beliveau R. Purification and characterization of a membrane-bound protein carboxyl methyltransferase from rat kidney cortex. J Biol Chem 1993;268:2610-2615. [PubMed: 8428937]

24. Yoo BC, Kang MS, Kim S, Lee YS, Choi SY, Ryu CK, Park GH, Han JS. Partial purification of protein farnesyl cysteine carboxyl methyltransferase from bovine brain. Exp Mol Med 1998;30:227234. [PubMed: 9894153]

25. Patwardhan AP, Thompson DH. Efficient synthesis of 40-and 48-membered tetraether macrocyclic bisphosphocholines. Org. Lett 1999;1:241-244. [PubMed: 10905869] 
26. Patwardhan AP, Thompson DH. Novel flexible and rigid tetraether acyclic and macrocyclic bisphosphocholines: synthesis and monolayer properties. Langmuir 2000;16:10340-10350.

27. Peanasky J, Schneider HM, Granick S, Kessel CR. Self-assembled monolayers on mica for experiments utilizing the surface forces apparatus. Langmuir 1995;11:953-962.

28. Groves JT, Boxer SG. Electric field-induced concentration gradients in planar supported bilayers. Biophys. J 1995;69:1972-1975. [PubMed: 8580340]

29. Cremer PS, Boxer SG. Formation and spreading of lipid bilayers on planar glass supports. J. Phys. Chem. B 1999;103:2554-2559.

30. Soumpasis DM. Theoretical-analysis of fluorescence photobleaching recovery experiments. Biophys. J 1983;41:95-97. [PubMed: 6824758]

31. Di Meglio C, Rananavare S, Svenson S, Thompson DH. Bolaamphiphilic phosphocholines: Structure and phase behavior in aqueous media. Langmuir 2000;16:128-133.

32. Schaffner W, Weissmann C. Rapid, sensitive, and specific method for determination of protein in dilute-solution. Anal. Biochem 1973;56:502-514. [PubMed: 4128882]

33. Schreiber SL, Wang Z, Schulte G. Group selective reduction of acetals related to the ansa chain of the streptovaricins -conformational and stereochemical analysis. Tet. Lett 1988;29:4085-4088.

34. Schwab P, France MB, Ziller JW, Grubbs RH. A series of well-defined metathesis catalysts -synthesis of $\left[\mathrm{RuCl}_{2}(=\mathrm{CHR})\left(\mathrm{PR}_{3}\right)_{2}\right]$ and its reactions. Angew. Chem. Int. Ed. Engl 1995;34:2039-2041.

35. Thompson DH, Svendsen CB, Di Meglio C, Anderson BC. Synthesis of chiral diether and tetraether phospholipids -regiospecific ring-opening of epoxy alcohol intermediates derived from asymmetric epoxidation. J. Org. Chem 1994;59:2945-2955.

36. Svenson S, Thompson DH. Facile and efficient synthesis of bolaamphiphilic tetraether phosphocholines. J. Org. Chem 1998;63:7180-7182. [PubMed: 11672358]

37. Febo-Ayala W, Holland DP, Bradley SA, Thompson DH. submitted.

38. Lee AG. Lipid-protein interactions in biological membranes: a structural perspective. Biochim. Biophys. Acta 2003;1612:1-40. [PubMed: 12729927]

39. Pilot JD, East JM, Lee AG. Effects of phospholipid headgroup and phase on the activity of diacylglycerol kinase of Escherichia coli. Biochemistry 2001;40:14891-14897. [PubMed: 11732909]

40. Cornelius F. Modulation of Na,K-ATPase and Na-ATPase activity by phospholipids and cholesterol. I. Steady-state kinetics. Biochemistry 2001;40:8842-8851. [PubMed: 11467945]

41. Killian JA. Hydrophobic mismatch between proteins and lipids in membranes. Biochim. Biophys. Acta 1998;1376:401-416. [PubMed: 9805000]

42. Tyminski PN, Latimer LH, O’Brien DF. Rhodopsin in polymerized bilayer-membranes. J. Amer. Chem. Soc 1985;107:7769-7760.

43. Tyminski PN, Latimer LH, O'Brien DF. Reconstitution of rhodopsin and the cGMP cascade in polymerized bilayer-membranes. Biochemistry 1988;27:2696-2705. [PubMed: 2840946]

44. Gibson NJ, Brown MF. Lipid headgroup and acyl chain composition modulate the MI-MII equilibrium of rhodopsin in recombinant membranes. Biochemistry 1993;32:2438-2454. [PubMed: 8443184]

45. Yamauchi K, Yamada K, Kinoshita M, Kamikawa T. Archaebacterial lipids -surface pressure-surface area isotherms of 1,1'-(1,32-dotriacontanediyl)bis[2-[3RS, 7R, 11R)-3,7,11,15-Tetramethylhexadecyl]sn-glycero-3-phosphocholine. Bull. Chem. Soc. Jpn 1991;64:2088-2090.

46. Yamauchi K, Sakamoto Y, Moriya A, Yamada K, Hosokawa T, Higuchi T, Kinoshita M. Archaebacterial lipid models -highly thermostable membranes from 1,1'-(1,32dotriacontamethylene)bis(2-phytanyl-sn-glycero-3-phosphocholine). J. Am. Chem. Soc 1990;112:3188-3191.

47. Jarrell HC, Zukotynski DA, Sprott GD. Lateral diffusion of the total polar lipids from Thermoplasma acidophilum in multilamellar liposomes. Biochim. Biophys. Acta 1998;1369:259-266. [PubMed: 9518643] 

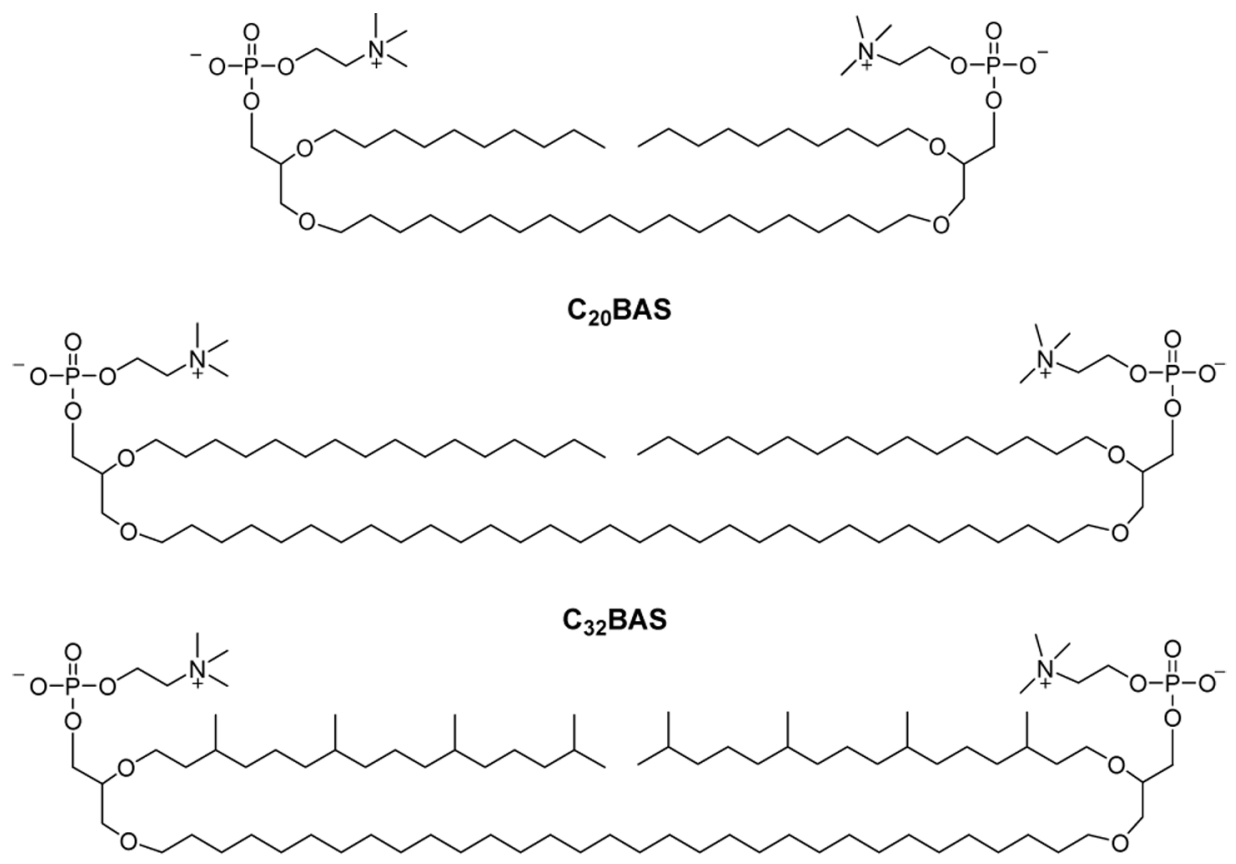

$\mathrm{C}_{32}$-phytBAS

Figure 1.

Structure of the synthetic bolalipids used in this study: $\mathrm{C}_{20} \mathrm{BAS}, \mathrm{C}_{32} \mathrm{BAS}$ and $\mathrm{C}_{32}$ phytBAS. 


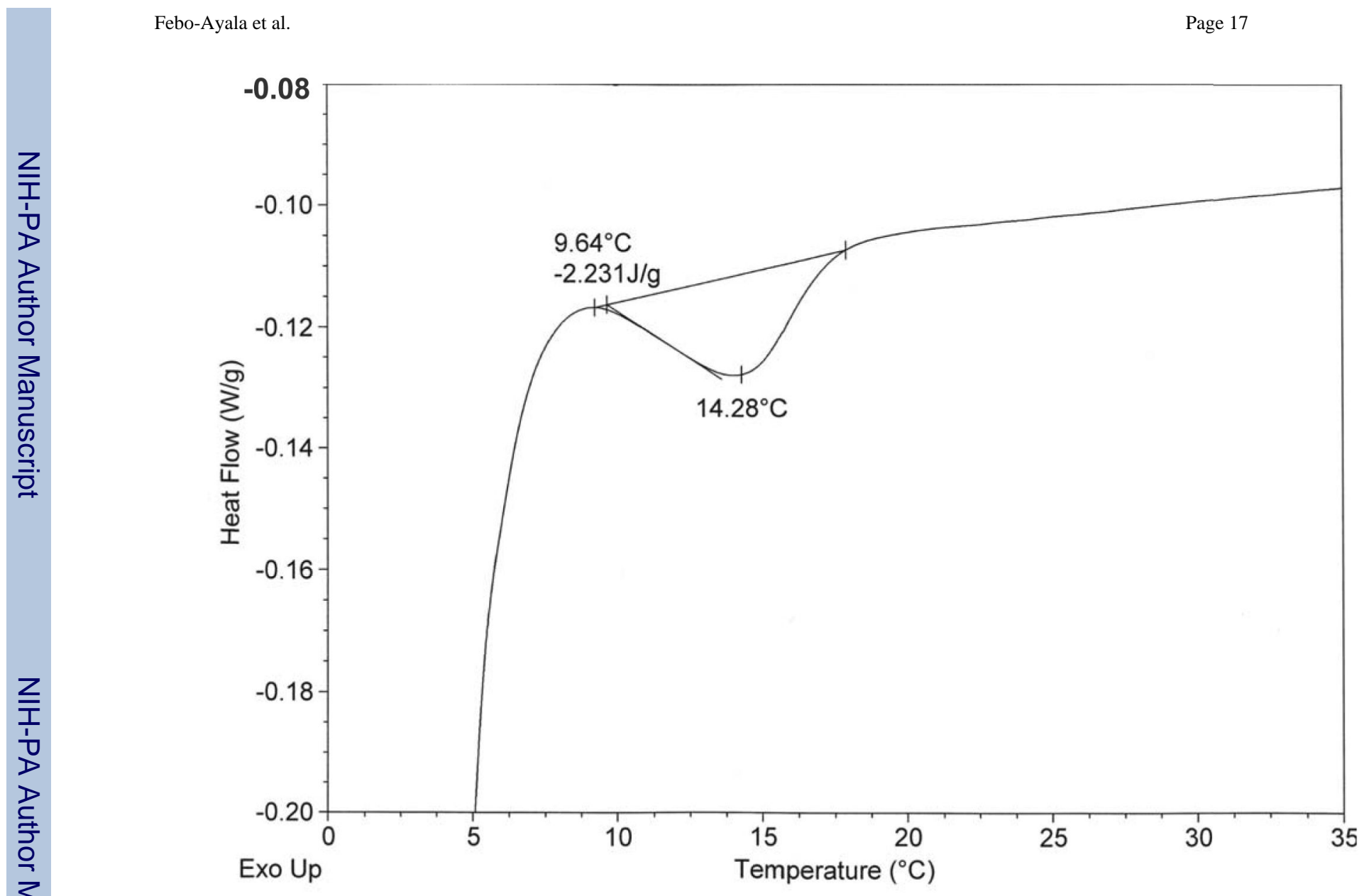

Biochemistry. Author manuscript; available in PMC 2008 November 14. 


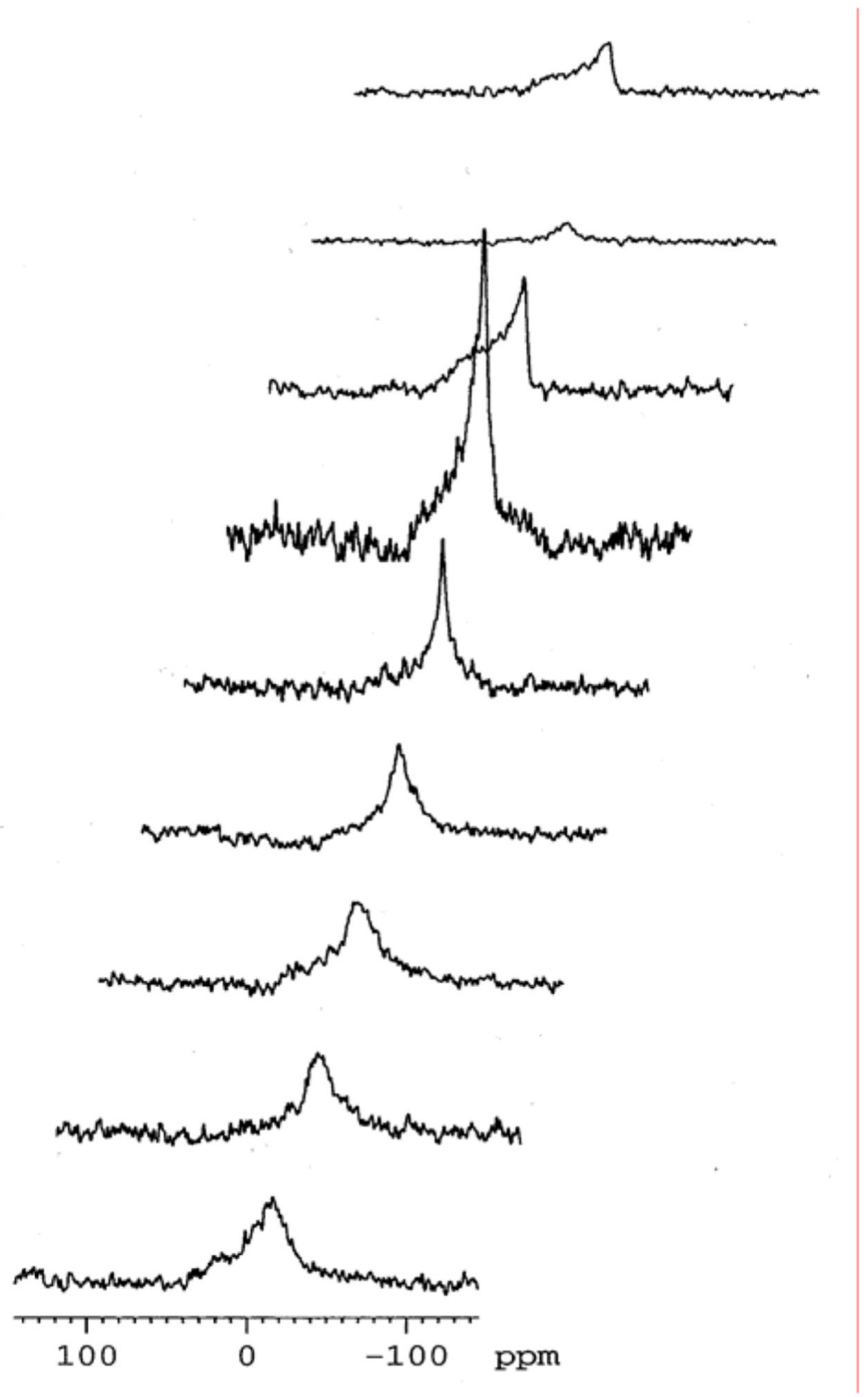

Figure 2.

Phase transition behavior of $\mathrm{C}_{32}$ phytBAS.

A: DSC of $\mathrm{C}_{32}$ phytBAS dispersion ( $1 \mathrm{mg}$ lipid $/ 4 \mu \mathrm{L} \mathrm{H}_{2} \mathrm{O}$ ) in sealed stainless steel pans, heating rate of $1{ }^{\circ} \mathrm{C} / \mathrm{min}$. One out of three trials is shown. The phase transition temperature $\left(\mathrm{T}_{\mathrm{m}}=14.3\right.$ $\left.{ }^{\circ} \mathrm{C}\right)$ and transition enthalpy $(-2.23 \mathrm{~J} / \mathrm{g})$ are displayed.

B: Temperature-dependent proton-decoupled ${ }^{31} \mathrm{P}$ NMR spectra of $\mathrm{C}_{32}$ phytBAS in $\mathrm{D}_{2} \mathrm{O}$. Top to bottom: $30,25,20,15,12,10,5,0,-5{ }^{\circ} \mathrm{C}$. The lipid was hydrated $\left(20 \mathrm{mg} \mathrm{lipid} / 1 \mathrm{~mL} \mathrm{D}_{2} \mathrm{O}\right)$ and extruded through $200 \mathrm{~nm}$ track-etch membranes. Typically, 1600 scans were acquired with a relaxation delay of $1 \mathrm{~s}, 90^{\circ}$ pulse of $6 \mu \mathrm{sec}$, acquisition time of $0.2 \mathrm{~s}$. The spectra were processed with a line broadening of $200 \mathrm{~Hz}$. 

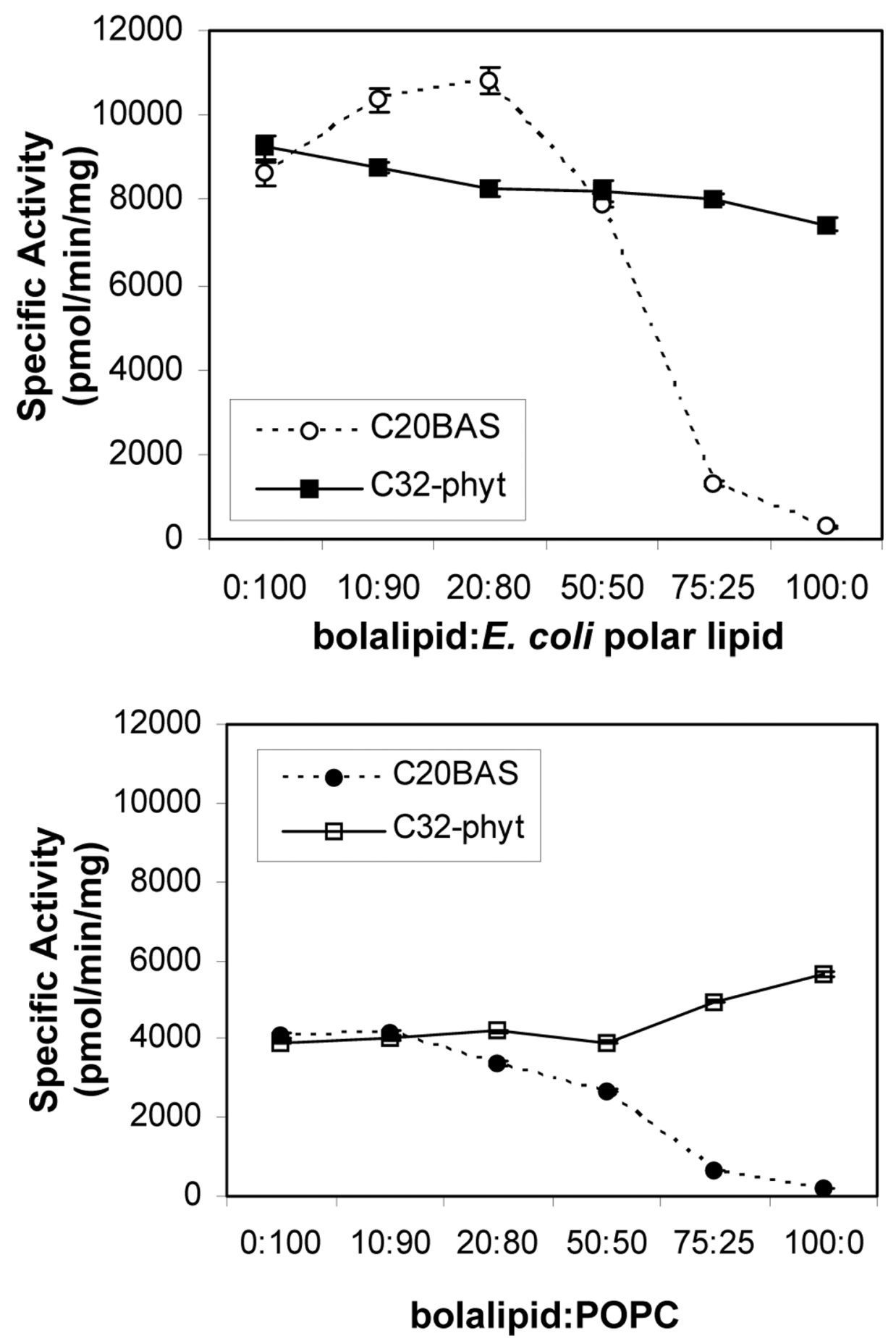

Figure 3.

Ste14p methyltransferase activity versus bolalipid:E. coli polar lipid composition (A), bolalipid:POPC composition (B). Ste $14 \mathrm{p}(\sim 1 \mu \mathrm{g})$ was added to $10 \mu \mathrm{L}$ of vesicle dispersion followed by $200 \mu \mathrm{M}$ AFC and rapid dilution by the addition of $20 \mu \mathrm{M}\left[{ }^{14} \mathrm{C}\right]-\mathrm{SAM}$. The samples were then incubated for $30 \mathrm{~min}$ at $30^{\circ} \mathrm{C}$ before quenching with $50 \mu \mathrm{L}$ of $1 \mathrm{M} \mathrm{NaOH} / 1 \%$ SDS. The mixture was spotted on a filter paper and analyzed by the vapor diffusion assay for $2.5 \mathrm{~h}$ 
as described in the Materials and Methods section. Specific activities were plotted as pmol of methyl groups transferred/mg protein/min. 

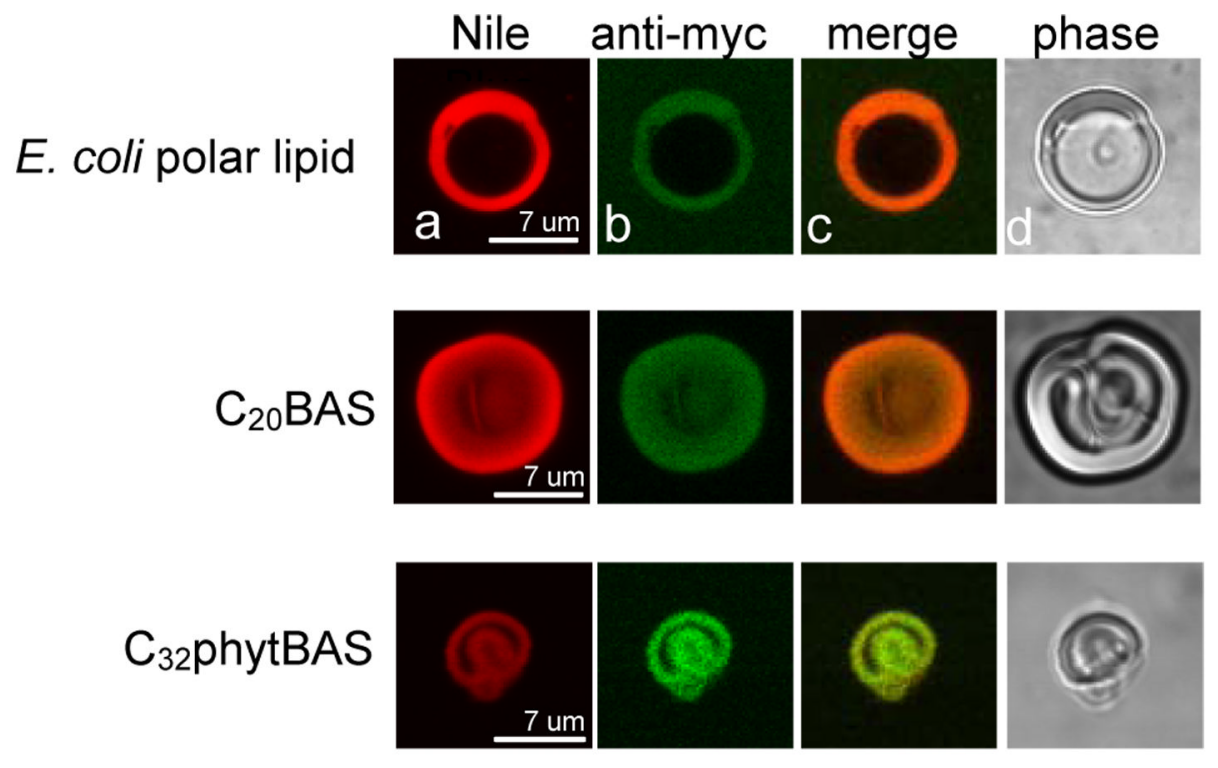

Figure 4.

Confocal immunofluorescence microscopy of giant vesicles of E. coli polar lipid (top), $\mathrm{C}_{20} \mathrm{BAS}$ (middle row), and $\mathrm{C}_{32}$ phytBAS (bottom row). Nile Blue was added to stain the membranes (column A) and Ste14p was stained with mouse anti-myc/goat FITC-anti-mouse antibodies (column B). The images from A and B were merged (column C); the phase contrast images appear in column D. Ste14p was reconstituted into unextruded vesicles for these experiments and imaged at $60 \times$ magnification. 

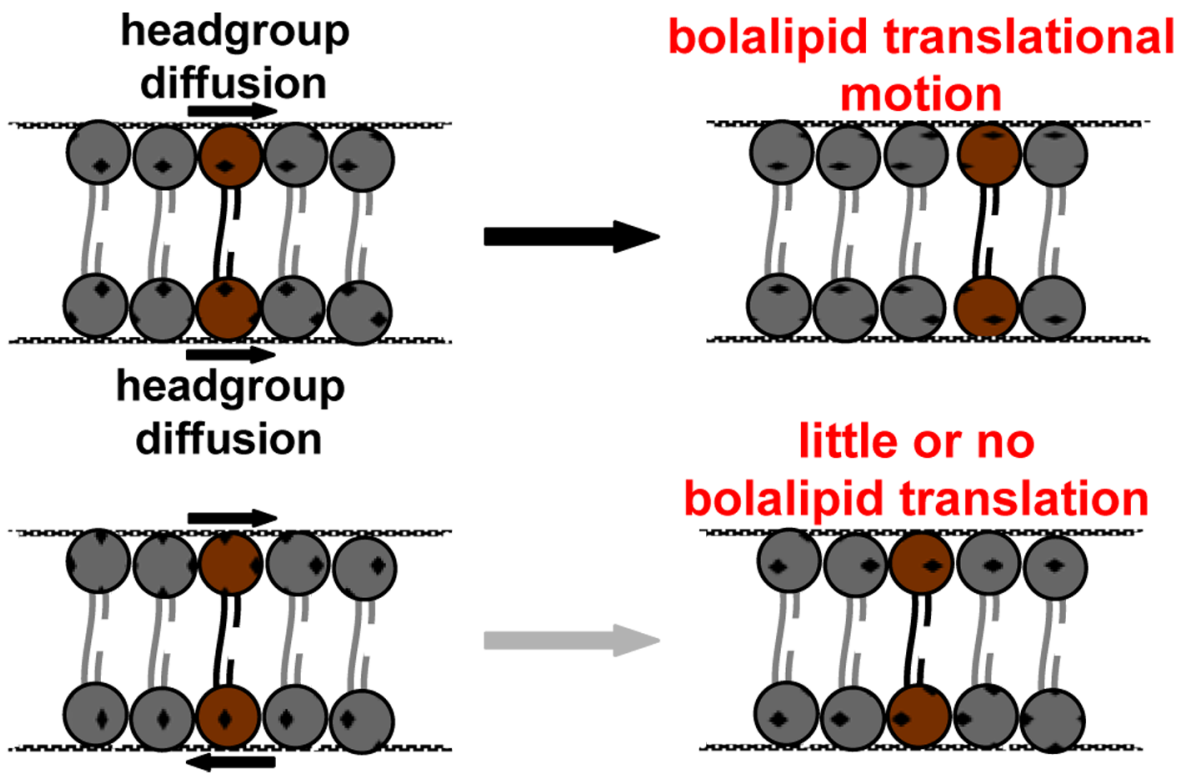

little or no
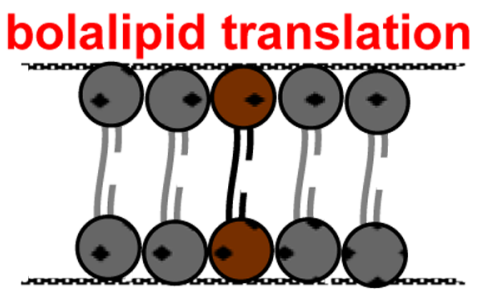

Figure 6.

Conceptual diagram of headgroup-coupled diffusion of bolalipids indicating the different outcomes of cooperative and uncooperative headgroup motions at the opposing membranewater interfaces. 

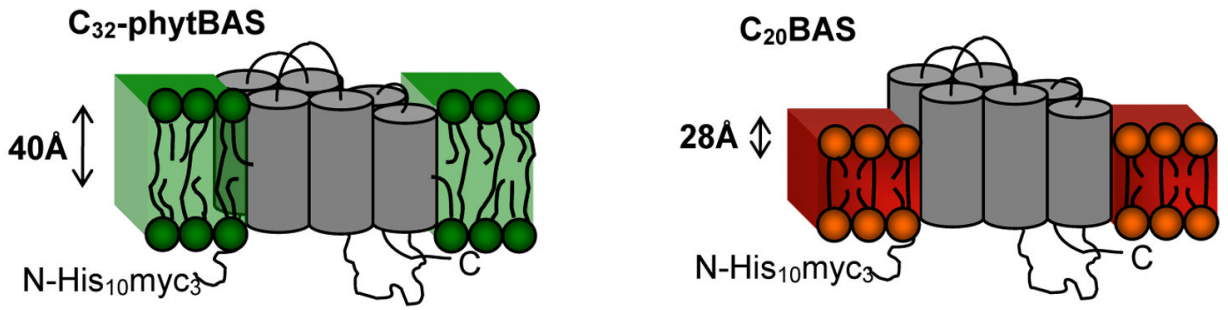

Figure 7.

Illustration of the hydrophobic mismatch and match between $\mathrm{C}_{20} \mathrm{BAS}$ and $\mathrm{C}_{32}$ phytBAS bolalipids and Ste14p, respectively. 


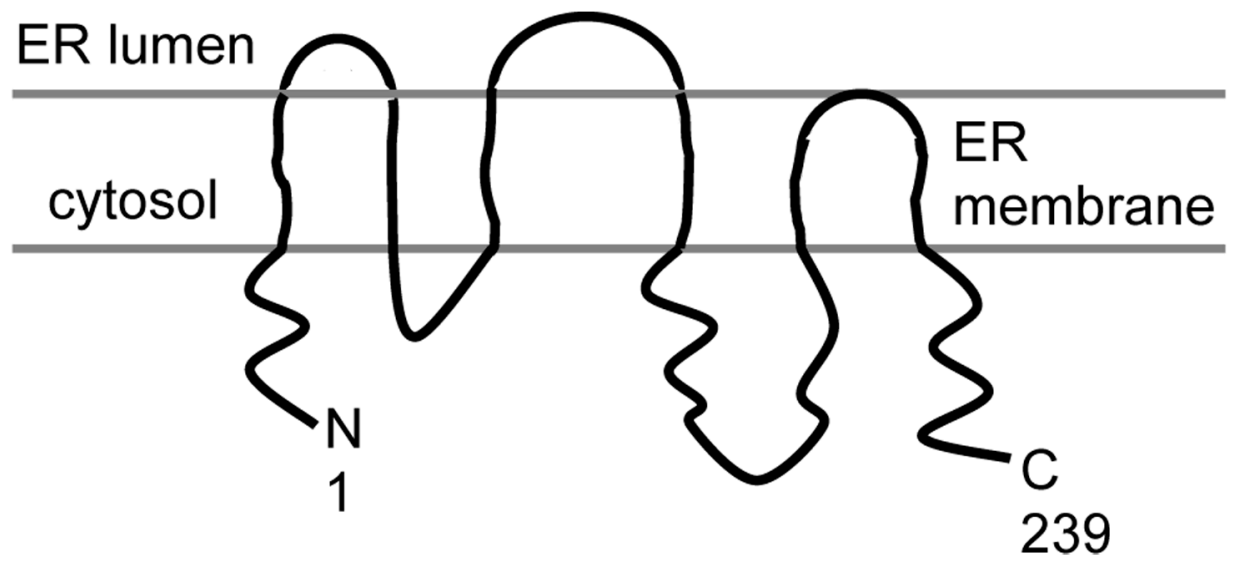

Scheme 1.

Topology model of Ste14p, adapted from (18). 
<smiles>CC(C)C(C)CCCC(C)(C)C(C)CCO</smiles>

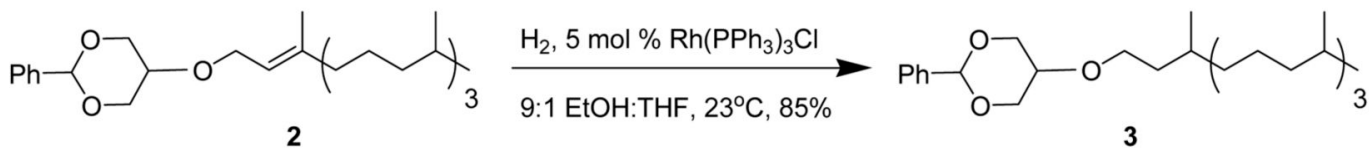

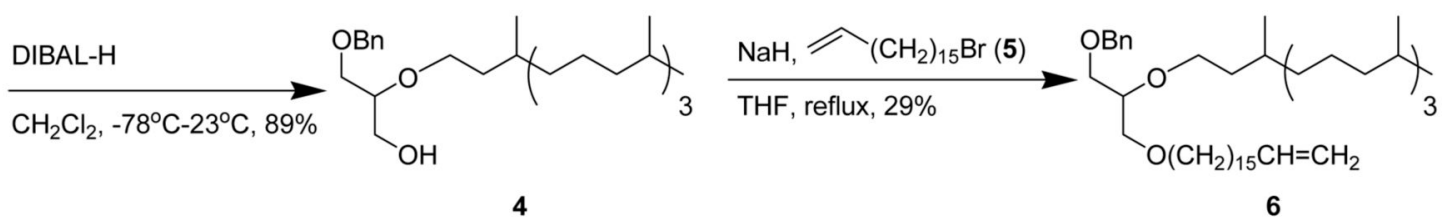

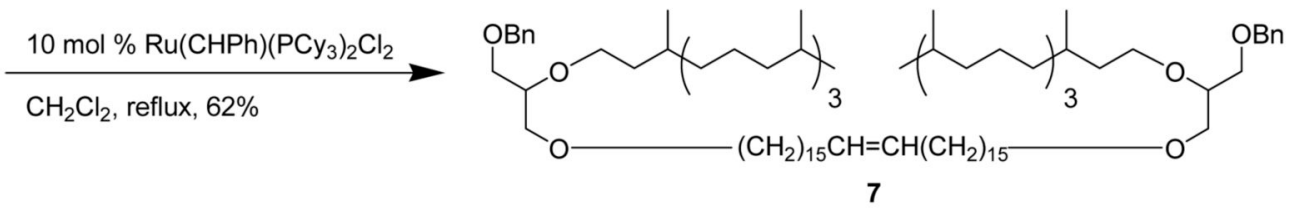

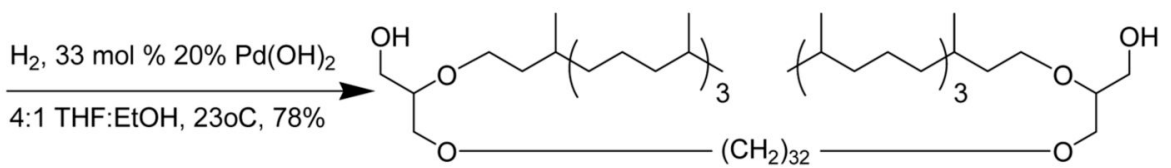

8

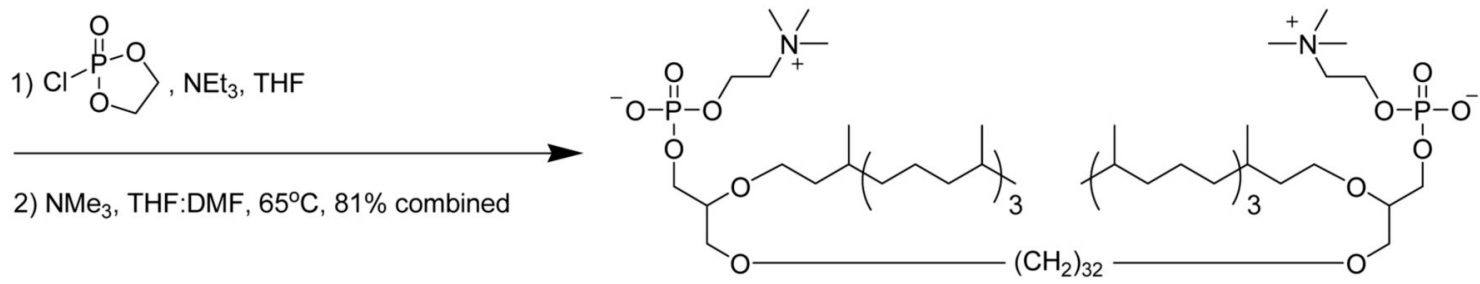
9

Scheme 2.

Synthesis pathway for $\mathrm{C}_{32}$ phytBAS. 


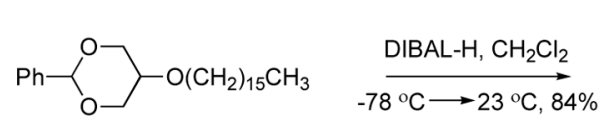

10

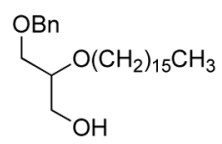

11
$\underset{\mathrm{PhCH}_{3} \|, 59 \%}{\mathrm{NaH}, \mathbf{5}}$

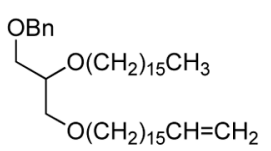

12

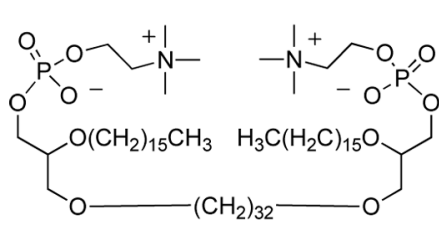

15

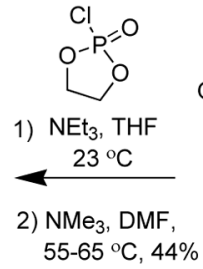

$55-65^{\circ} \mathrm{C}, 44 \%$

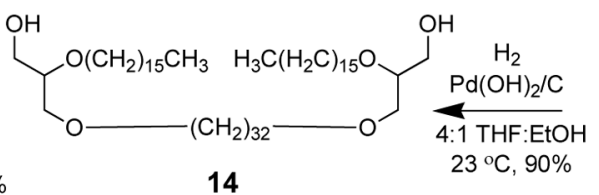

14

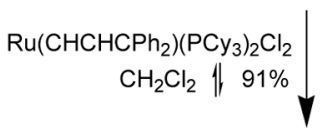

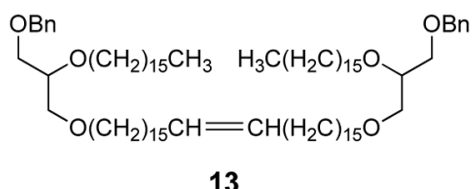

Scheme 3.

Synthesis pathway for $\mathrm{C}_{32} \mathrm{BAS}$. 

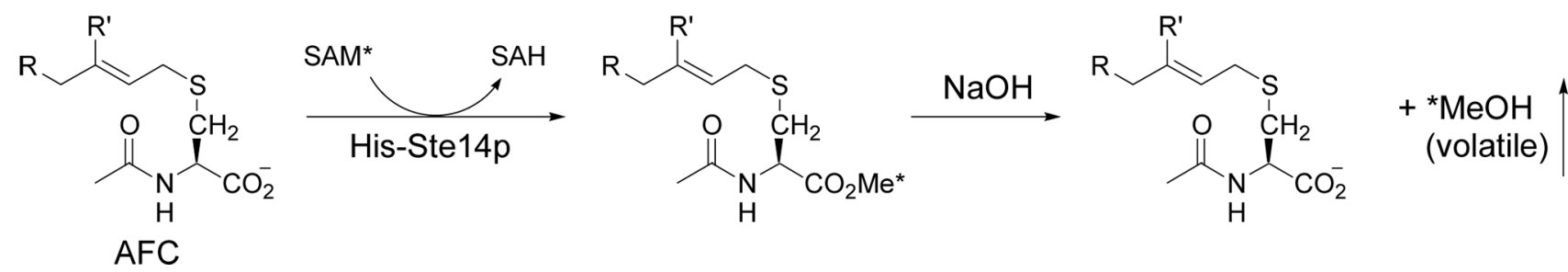

Scheme 4.

Vapor Diffusion Assay Reaction. 
Table 1

Gel-to-liquid crystalline phase transition temperatures for hydrated bolalipids determined by differential scanning calorimetry.

\begin{tabular}{c|c|c|}
\cline { 2 - 2 } & Bolalipid & $\mathbf{T}_{\mathbf{m}}\left({ }^{\circ} \mathbf{C}\right)$ \\
\cline { 2 - 3 } & $\mathrm{C}_{32}$ phytBAS & $14 \pm 0.1$ \\
\hline $\mathrm{C}_{20}$ BAS & $17 \pm 0.3$ \\
\hline $\mathrm{C}_{32}$ BAS & $>85$ \\
\hline \multirow{2}{*}{} &
\end{tabular}


Table 2

Lateral diffusion coefficients of NBD-OPPC in lipid membranes on glass determined by fluorescence recovery after photobleaching.

\begin{tabular}{|c|c|c|}
\hline & Lipid & $\underset{\left(\times 10^{8} \mathrm{~cm}^{2} / \mathrm{s}\right.}{ }$ \\
\hline & POPC & $8.0 \pm 2.2$ \\
\hline & $\mathrm{C}_{20}$ BAS:POPC & $3.6 \pm 0.3$ \\
\hline & $\mathrm{C}_{20} \mathrm{BAS}$ & $1.5 \pm 0.1$ \\
\hline & 7:3 C $\mathrm{C}_{20}$ BAS:chol & $0.12 \pm 0.03$ \\
\hline & $\mathrm{C}_{32}$ phytBAS & $0.18 \pm 0.03$ \\
\hline
\end{tabular}




\section{Table 3}

Specific activity of Ste14p (pmol/min/mg) as a function of lipid type and their gel-to-liquid crystalline phase transition temperatures. Ste $14 \mathrm{p}$ reconstitutions in all lipid types were all conducted at $32{ }^{\circ} \mathrm{C}$; the methyltransferase reactions were subsequently incubated at the temperatures indicated in parentheses for each lipid measured. The precision of the specific activity measurements are $\pm 3 \%$.

\begin{tabular}{|c|c|c|c|}
\hline Lipid & $\mathbf{T}_{\mathbf{m}}\left({ }^{\circ} \mathbf{C}\right)$ & $\begin{array}{c}\begin{array}{c}\text { Specific Activity, Below } \mathbf{T}_{\mathrm{m}} \\
\left(\text { Assav Temp, }{ }^{\circ} \mathrm{C}\right)\end{array} \\
\end{array}$ & $\begin{array}{c}\begin{array}{c}\text { Specific Activity, Above } \mathbf{T}_{\mathrm{m}} \\
\left(\text { Assav Temp, }{ }^{\circ} \mathrm{C}\right)\end{array} \\
\end{array}$ \\
\hline E. coli polar lipid & $6-24^{\dagger}$ & $6240(10)$ & -- \\
\hline “ & “ & - & $6820(30)$ \\
\hline “ & “ & - & $7140(32)$ \\
\hline “ & “ & -- & $6560(44)$ \\
\hline $\mathrm{C}_{20} \mathrm{BAS}$ & 17 & $290(10)$ & $310(32)$ \\
\hline DMPC & 23 & $6450(16)$ & $6630(32)$ \\
\hline
\end{tabular}

${ }^{\dagger}$ M. Esfahani, et al., Proc. Natl. Acad. Sci. USA (1971) 68, 3180. 